Article

\title{
Genome-Wide Profiling of Enterotoxigenic Staphylococcus aureus Strains Used for the Production of Naturally Contaminated Cheeses
}

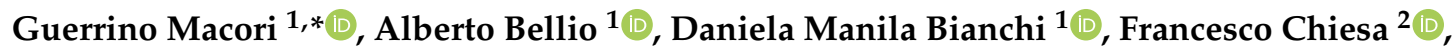 \\ Silvia Gallina ${ }^{1}$, Angelo Romano ${ }^{1}{ }^{\circledR}$, Fabio Zuccon ${ }^{1}$, Raúl Cabrera-Rubio ${ }^{3}$, Alexandra Cauquil ${ }^{4}$, \\ Déborah Merda ${ }^{4}{ }^{\oplus}$, Fréderic Auvray ${ }^{4}$ and Lucia Decastelli ${ }^{1}$ \\ 1 National Reference Laboratory for Coagulase-Positive Staphylococci including Staphylococcus aureus, \\ Istituto Zooprofilattico Sperimentale del Piemonte, Liguria e Valle d'Aosta, Via Bologna 148, 10154 Torino, \\ Italy; alberto.bellio@gmail.com (A.B.); manila.bianchi@izsto.it (D.M.B.); silvia.gallina@izsto.it (S.G.); \\ angelo.romano@izsto.it (A.R.); fabio.zuccon@izsto.it (F.Z.); lucia.decastelli@izsto.it (L.D.) \\ 2 Dipartimento di Scienze Veterinarie, Università di Torino, 10095 Grugliasco, Italy; francesco.chiesa@unito.it \\ 3 Teagasc Food Research Centre, Moorepark, Fermoy, P61 C996, Ireland-APC Microbiome Ireland, \\ University College Cork, T12YT20 Cork, Ireland; Raul.CabreraRubio@teagasc.ie \\ 4 European Laboratory for Coagulase-Positive Staphylococci including Staphylococcus aureus, Laboratory for \\ Food Safety, ANSES, Université Paris-Est, F-94700 Maisons-Alfort, France; \\ Alexandra.Cauquil@anses.fr (A.C.); Deborah.merda@anses.fr (D.M.); f.auvray@envt.fr (F.A.) \\ * Correspondence: guerrino.macori@gmail.com; Tel.: +39-01-1268-6225
}

Received: 9 November 2019; Accepted: 22 December 2019; Published: 27 December 2019

\begin{abstract}
Staphylococcus aureus is a major human pathogen and an important cause of livestock infections. More than 20 staphylococcal enterotoxins with emetic activity can be produced by specific strains responsible for staphylococcal food poisoning, one of the most common food-borne diseases. Whole genome sequencing provides a comprehensive view of the genome structure and gene content that have largely been applied in outbreak investigations and genomic comparisons. In this study, six enterotoxigenic $S$. aureus strains were characterised using a combination of molecular, phenotypical and computational methods. The genomes were analysed for the presence of virulence factors (VFs), where we identified 110 genes and classified them into five categories: adherence $(n=31)$, exoenzymes $(n=28)$, genes involved in host immune system evasion $(n=7)$; iron uptake regulatory system $(n=8)$; secretion machinery factors and toxins' genes $(n=36)$, and 39 genes coding for transcriptional regulators related to staphylococcal VFs. Each group of VFs revealed correlations among the six enterotoxigenic strains, and further analysis revealed their accessory genomic content, including mobile genetic elements. The plasmids pLUH02 and pSK67 were detected in the strain ProNaCC1 and ProNaCC7, respectively, carrying out the genes sed, ser, and selj. The genes carried out by prophages were detected in the strain ProNaCC2 (see), ProNaCC4, and ProNaCC7 (both positive for sea). The strain ProNaCC5 resulted positive for the genes seg, sei, sem, sen, seo grouped in an exotoxin gene cluster, and the strain ProNaCC6 resulted positive for seh, a transposon-associated gene. The six strains were used for the production of naturally contaminated cheeses which were tested with the European Screening Method for staphylococcal enterotoxins. The results obtained from the analysis of toxins produced in cheese, combined with the genomic features represent a portrait of the strains that can be used for the production of staphylococcal enterotoxin-positive cheese as reference material.
\end{abstract}

Keywords: staphylococcal enterotoxins; annotation; Staphylococcus aureus 


\section{Introduction}

The advances in sequencing technologies, including next generation sequencing (NGS) have contributed to the revolution of food safety, facilitating the detection and characterisation of foodborne pathogens [1-3]. Since their first applications in the phylogenetic analysis of pathogens and spoilage microorganisms, it has been possible to reveal genomic clusters [4] and genes that are crucial for host colonisation and bacterial propagation during infection [5]. Some noticeable examples are the use of genotyping assays for molecular differentiation [6] and the use of new approaches and models for the study of complex microbial communities [7,8]. High throughput DNA sequencing technologies, moreover, can be applied for the study of accessory elements that confer genetic diversity in prokaryotic organisms [9] as well as comparative genomics studies. These approaches have crucial roles enlightening important features, such as antimicrobial resistance [10,11], and for discovering potential virulence factors $(\mathrm{VFs})[12,13]$.

Whole genome sequencing (WGS) provides a comprehensive view of the genome structure and gene content of microorganisms [14-16], and is now gradually replacing well-recognised, standardised protocols like PulseNet for its higher sensitivity, specificity, and inter-laboratory comparability, as well as timely resolution when compared with traditional molecular methods $[17,18]$. WGS has been applied for genomic comparison of microorganisms associated with foodborne outbreaks and for surveillance of high-burden diseases for almost a decade [15], allowing the identification of pathogens in the foods responsible for the infections [15,19-21]. In fact, precise gene identifications and detailed virulence portraits can be determined in a single session of sequencing, while bioinformatics analysis for foodborne pathogens provides valuable resources for databases and collections of genomic features [22].

One of the most common foodborne related diseases is the staphylococcal food poisoning (SFP), resulting from the consumption of foods containing sufficient amounts of staphylococcal enterotoxins (SEs) [23]. SFP is associated with enterotoxigenic S. aureus (S. aureus) strains that may produce one or more heat-stable enterotoxins in food, causing vomiting and abdominal pain in humans [24]. In 2015, 9.9\% of all European outbreaks were caused by SEs [25], indicating the importance of surveillance plans and publication of updated reports for risk assessment evaluations. Indeed, the detection of SEs for milk products is a microbiological criterion included into the Commission Regulation (EC) No 2073/2005 [26].

To date, 26 different staphylococcal superantigens (SAgs) have been identified, including the staphylococcal enterotoxins (SEA to SEE; SEG to SEI; SEK; SEM to SET) reported as responsible agents for foodborne outbreaks [27-29]; the staphylococcal enterotoxin-like toxins (SElJ; SEIL; SEIU to SElZ) which are a group of SEs that are not emetic in a primate model, or, their relationship with food poisoning, have yet to be experimentally demonstrated [30-33]; and the toxic shock syndrome toxin (TSST-1) [34]. Several studies were focused on the genes and the molecular bases of the infections, including emetic studies of newly discovered enterotoxins [35-38], other virulence factors [39,40] and superantigenic properties of SEls [41]. The genes encoding for S. aureus VFS are carried by mobile genetic elements (MGEs) and consist of prophages, plasmids, transposons, and S. aureus pathogenicity islands (SaPIs) [42,43], which encode, among the others, enterotoxins and adhesins [23,44]. MGEs mediate their own transfer and integration into new genomic sites and, with a phenomenon called horizontal gene transfer (HGT), also among other bacteria, cause adaptive consequences, such as the transfer and acquisition of antibiotic resistance genes [45]. In this study, six enterotoxigenic $S$. aureus strains were genome-sequenced. A report of their virulence portraits is presented, and the databases used for the detection of the genomic features are described. The strains were also used for the production of naturally contaminated cheeses, suggesting new opportunities for the production of reference materials for inter-laboratory tests, required by regulations [46]. The results obtained from the analysis of toxins produced in cheese, and the comparison with the genomic data, highlighted the requirement of validated methods for the detection of enterotoxins that are more effective. In time, the genes portrait will be translated to provide an effective tool for the detection of the factors responsible for the production of SEs in vivo and predict the enterotoxins that can be produced in 
complex matrices, which is valuable for surveillance management and corrective action strategies in processing facilities.

\section{Materials and Methods}

\subsection{Bacterial Study Isolates and Sample Preparation}

The experiments were performed using a number of archived strains of $S$. aureus which were maintained in cryogenic vials stock culture beads at $-80{ }^{\circ} \mathrm{C}$ in two collections: at the European Reference Laboratory for Coagulase Positive Staphylococci, (EURL CPS, Maisons-Alfort, France) and at the Italian Reference Laboratory for CPS (ITRL CPS, Turin, Italy). Six S. aureus strains were chosen for this study, representing enterotoxin producers isolated from cheese (five strains) and one strain isolated from a composed salad. Among the six strains, three were isolated in cheeses, which resulted as being responsible for foodborne poisoning involving patients (Table 1). 
Table 1. Origin and details of the strains selected for this study.

\begin{tabular}{|c|c|c|c|c|c|c|c|}
\hline Strain & Origin & Year & City, Country & Etiological Food & Patients & Symptoms $^{1}$ & Reference \\
\hline ProNaCC1 & Routine analysis & 2009 & $\begin{array}{l}\text { Haute-Savoie, } \\
\text { France }\end{array}$ & $\begin{array}{l}\text { Cheese } \\
\text { (Tomme) }\end{array}$ & Not involved & Not reported & This study \\
\hline ProNaCC2 & Staphylococcal Food-borne Poisoning & 2009 & Sommes, France & $\begin{array}{c}\text { Cheese } \\
\text { (Mont d'Or du Jura) }\end{array}$ & 23 & $\begin{array}{c}\mathrm{AC}, \mathrm{D}, \mathrm{F}, \mathrm{N} \\
\mathrm{V}\end{array}$ & [47] \\
\hline ProNaCC4 & Staphylococcal Food-borne Poisoning & 2012 & $\begin{array}{l}\text { Hautes-Vienne, } \\
\text { France }\end{array}$ & $\begin{array}{c}\text { Cheese } \\
\text { (Basque Lait Cru Brebis) }\end{array}$ & 3 & $A C, D, N, V$ & This study \\
\hline ProNaCC5 & Staphylococcal Food-borne Poisoning & 2014 & Loire, France & $\begin{array}{l}\text { Cheese } \\
\text { (Raclette) }\end{array}$ & 5 & $\mathrm{AC}, \mathrm{D}, \mathrm{V}$ & This study \\
\hline ProNaCC6 & Routine analysis & 2014 & $\begin{array}{l}\text { Alpes de Haute } \\
\text { Provence, France }\end{array}$ & $\begin{array}{l}\text { Composed Salad } \\
\text { (tuna-corn-beets-apple) }\end{array}$ & Not involved & Not reported & This study \\
\hline ProNaCC7 & Routine analysis & 2015 & Vercelli, Italy & $\begin{array}{l}\text { Cheese } \\
\text { (Tomme) }\end{array}$ & Not involved & Not reported & [48] \\
\hline
\end{tabular}

${ }^{1}$ Detailed information about the symptoms reported: AC: Abdominal cramps; D: diarrhoea; F: Fever; N: Nausea; V: Vomiting. 
To regenerate the bacteria, one bead was placed in $10 \mathrm{~mL}$ of tryptone soya broth (TSB) (Basingstoke, Oxoid, UK) and incubated statically for $24 \mathrm{~h}$ at $37^{\circ} \mathrm{C}$. A total of $10 \mu \mathrm{L}$ were plated on tryptone soya agar (TSA) (Basingstoke, Oxoid, UK) and incubated for $24 \mathrm{~h}$ at $37^{\circ} \mathrm{C}$ for checking purity and obtaining single colonies. Species confirmation was performed by a VITEK system GP card (bioMérieux, Marcy

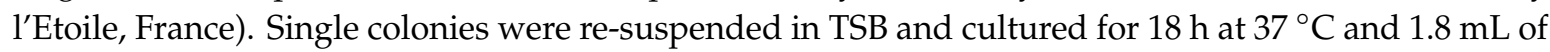
the pure cultures were used for DNA isolation with DNeasy UltraClean Microbial Kit (Qiagen, Milan, Italy) following the manufacturer's protocol. Quality and DNA concentrations were determined with a Qubit 2.0 fluorometer (Invitrogen, Monza, Italy) and Agilent 2100 bioanalyzer (Agilent, Leini, Italy).

\subsection{Detection of Staphylococcal Enterotoxin Genes by Multiplex PCR Assay, Typing and Antimicrobial Susceptibility Testing}

The strains were analysed for the presence of 11 enterotoxins using 2 multiplex PCR assays (mPCR) according to the EURL CPS methods [49,50]. The protocols included the detection of the genes from sea to see and ser for the first MPCR (annealing temperature was $55^{\circ} \mathrm{C}$ ) and from seg to selj and ser for the second mPCR (annealing temperature was $52{ }^{\circ} \mathrm{C}$ ); the primers used are reported in Table 2. Five reference $S$. aureus strains were used as positive controls for the SEs genes: S. aureus FRIS6 (positive for sea, seb), S. aureus FRI137 (positive for seg, seh, sei), S. aureus FRI326 (positive for see), S. aureus FRI361 (positive for sec, sed, ser), and S. aureus HMPL280 (positive for seg, sei, selj, sep).

Multilocus sequence typing (MLST) was performed on S. aureus isolates targeting seven housekeeping genes ( $a r o E, p t a, g l p F, a r c C, g m k, t p i$, and yqiL) according to Enright et al. [51]. Strains were further characterised by spa typing following the method developed by Harmsen and colleagues [52].

Table 2. Primers used for this study. The amplification conditions were the same for both the first mPCR (sea to see and ser) and second MPCR (seg to selj and ser), except the annealing temperature (respectively $55^{\circ} \mathrm{C}$ and $52{ }^{\circ} \mathrm{C}$ ): initial denaturation $94^{\circ} \mathrm{C}$ for $3 \mathrm{~min} ; 35$ cycles of denaturation $\left(94{ }^{\circ} \mathrm{C}\right.$ for $30 \mathrm{~s})$, annealing (30 s), extension $\left(72{ }^{\circ} \mathrm{C}\right.$ for $\left.90 \mathrm{~s}\right)$; final extension $72{ }^{\circ} \mathrm{C}$ for $7 \mathrm{~min}$.

\begin{tabular}{|c|c|c|c|c|}
\hline Gene & Name Primer & Sequence $\left(5^{\prime}-3^{\prime}\right)$ & Product Size (bp) & Reference \\
\hline \multirow{2}{*}{ sea } & GSEAR-1 & GGT TAT CAA TGT GCG GGT GG & \multirow{2}{*}{102} & \multirow{2}{*}{ [53] } \\
\hline & GSEAR-2 & CGG CAC TTT TTT CTC TTC GG & & \\
\hline \multirow{2}{*}{ seb } & GSEBR-1 & GTA TGG TGG TGT AAC TGA GC & \multirow{2}{*}{164} & \multirow{2}{*}{ [53] } \\
\hline & GSEBR-2 & CCA AAT AGT GAC GAG TTA GG & & \\
\hline \multirow{2}{*}{$\sec$} & GSECR-1 & AGA TGA AGT AGT TGA TGT GTA TGG & \multirow{2}{*}{451} & \multirow{2}{*}{ [53] } \\
\hline & GSECR-2 & CAC ACT TTT AGA ATC AAC CG & & \\
\hline \multirow{2}{*}{ sed } & GSEDR-1 & CCA ATA ATA GGA GAA AAT AAA AG & \multirow{2}{*}{278} & \multirow{2}{*}{ [53] } \\
\hline & GSEDR-2 & ATT GGT ATT TTT TTT CGT TC & & \\
\hline \multirow{2}{*}{ see } & SA-U & TGT ATG TAT GGA GGT GTA AC & \multirow{2}{*}{213} & \multirow{2}{*}{ [53] } \\
\hline & SA-E rev & GCC AAA GCT GTC TGA G & & \\
\hline \multirow{2}{*}{ ser } & SER 1 & AGA TGT GTT TGG AAT ACC CTA T & \multirow{2}{*}{123} & \multirow{2}{*}{ [53] } \\
\hline & SER 2 & CTA TCA GCT GTG GAG TGC AT & & \\
\hline \multirow{2}{*}{ seg } & SEG-F & GTT AGA GGA GGT TTT ATG & \multirow{2}{*}{198} & \multirow{2}{*}{ [54] } \\
\hline & SEG-R & TTC CTT CAA CAG GTG GAG A & & \\
\hline \multirow{2}{*}{ seh } & SEH-F & CAA CTG CTG ATT TAG CTC AG & \multirow{2}{*}{173} & \multirow{2}{*}{ [54] } \\
\hline & SEH-R & CCC AAA CAT TAG CAC CA & & \\
\hline \multirow{2}{*}{ sei } & SEI-F & GGC CAC TTT ATC AGG ACA & \multirow{2}{*}{328} & \multirow{2}{*}{ [54] } \\
\hline & SEI-R & AAC TTA CAG GCA GTC CA & & \\
\hline \multirow{2}{*}{ selj } & SEJ-F & GTT CTG GTG GTA AAC CA & \multirow{2}{*}{131} & \multirow{2}{*}{ [54] } \\
\hline & SEJ-R & GCG GAA CAA CAG TTC TGA & & \\
\hline \multirow{2}{*}{ sep } & SEP-F & TCA AAA GAC ACC GCC AA & \multirow{2}{*}{396} & \multirow{2}{*}{ [54] } \\
\hline & SEP-R & ATT GTC CTT GAG CAC CA & & \\
\hline
\end{tabular}


To determine the susceptibility to antimicrobials, Vitek 2 (bioMérieux, Marcy l'Etoile, France) testing was performed using software version 5.04 and the AST-GP79 cards for S. aureus, according to the manufacturer's instructions. The six strains were analysed for the presence of genes mecA and mecC (methicillin resistant $S$. aureus factors-MRSA) along with the genes pol (Panton-Valentine Leukocidin—PVL) and spa, according to the method by Stegger et al. [53].

\subsection{Whole-Genome Sequencing, and Bioinformatics Analysis}

Genomic libraries were prepared using the Illumina Nextera library preparation kit for each strain following the manufacturer's protocol. WGS was carried out on the Illumina MiSeq platform. The quality of the reads was assessed using FastQC (version 0.11.5) [53]. Specifically, reads were filtered for length, while those with a quality score less than Q30 were discarded using Trimmomatic (version 0.36) [54]. De-novo contigs were generated using SPAdes (v.3.9.1) [55], and the quality of each assembled genome was assessed with QUAST (v.4.3) [56]. The assemblies were annotated using Prokka (v.1.11) [57] and RAST [58] for the prediction of coding sequences (CDSs).

\subsection{Identification of Virulence Factors and Genomic Analysis}

The genomes were interrogated for a pool of 1300 genes, including VFs reported for staphylococci and determined using a combination of a database built for this study (Supplementary Material Database S1) and the PATRIC tool (http://patricbrc.org) (v3.5.41) [59]. The VFs were classified into six functional categories: genes involved in adherence, exoenzymes, host immune evasion factors, iron uptake and metabolism, toxins and transcriptional regulatory elements. Antibiotic resistance genes were detected from the assemblies using ABRicate v0.7 (https:/github.com/tseemann/abricate) interrogating the comprehensive antibiotic resistance database (CARD) (https://card.mcmaster.ca). ABRicate was used for the creation of three novel databases built for the detection of SaPIs (Supplementary Material Database S5), plasmids (S7), and genes coding for enterotoxins (S3). The sequences were searched within the genomes of all isolates, consequently, their presence was validated using BLAST+ (v.2.5.0) applying a cut-off value of $\geq 80 \%$ base identity and $\geq 95 \%$ coverage. In silico, MLST was performed using the dedicated server [60] to determine whether any isolates might have been misassigned in the MLST scheme. Bagel3 was used for the detection of genes encoding bacteriocins [61] and prophages sequences were searched to verify the contribution of integrative elements in the structure of bacterial genomes and virulence factors; their sequences were predicted using the PHAge Search Tool (PHASTER) [62]. The annotated genomes were used as input for calculating the pangenome with Roary v.3.12.0 [63] and Anvi'o 2.0.2 [64] and visualized using Phandango [65]. In order to avoid ambiguities in taxonomic inferences, the average nucleotide identity (ANI) comparison of the six genomes was carried out using two independent ANI determination methods: ANI Calculator (http://enve-omics.ce.gatech.edu/ani/index) and EzGenome (http://www.ezbiocloud.net/ezgenome/ani). The genomes of 29 enterotoxigenic $S$. aureus strains were used for the genomic comparison of the six strains presented in this study and included in the constructing of the pan-genome, which was annotated with the use of the Clusters of Orthologous Groups (COGs) database [66]. The genomes were obtained from the assembly database (https://www.ncbi.nlm.nih.gov/assembly/), and the details of the strains are reported in the Supplemental Table S2. All the tools and software were used with default settings if not specified, and data in figures or intext are presented as mean $+/-$ one standard error of the mean unless otherwise indicated. Heatmaps and standard statistical analyses were conducted in RStudio v.1.2.1335 ( $R$ Core Team 2018). For the construction of the approximate maximum likelihood phylogenetic tree, FastTree was used [67]. In addition, the tool was used for generating the phylogenetic tree and the pangenome matrix. 
2.5. Production of the Natural Contaminated Cheese and Detection of Preformed Staphylococcal Enterotoxins in Milk and Cheese

The strains used in this study were tested for the production of SEs in broth culture. Briefly, two colonies from TSA were transferred to $10 \mathrm{~mL}$ of TSB and statically incubated at $37^{\circ} \mathrm{C}$ for $18 \mathrm{~h}$. The cultures in broths were centrifuged for $5 \mathrm{~min}$ at $3500 \times g$ at $10^{\circ} \mathrm{C}$, and the supernatant and cell debris were removed by filtrationwith $0.22 \mu \mathrm{m}$ filters. SEs detection was performed with the use of commercially available polyvalent enzyme-linked immunoassay (ELISA) RIDASCREEN SET Total (R-Biopharm AG, Darmstadt, Germany) and enzyme-linked fluorescent immunoassay (ELFA), Vidas SET2 (bioMérieux, Marcy l'Etoile, France). These reference methods can simultaneously detect SEA to SEE in food matrices without differentiating the five SEs [68].

The six strains selected for this study were used for inoculating bovine pasteurised whole milk (GS, Milan, Italy) followed by the production of 12 batches of cheese (two for each strain). For obtaining a batch of SE-positive cheese, each TSA pure culture of the strains were re-suspended in $30 \mathrm{~mL}$ of sterile $0.85 \% \mathrm{NaCl}$ solution obtaining a $3 \mathrm{McFarland}$ unit suspension that was inoculated into $10 \mathrm{~L}$ of milk, corresponding to $9 \times 10^{8} \mathrm{CFU} / \mathrm{mL}$. The milk was incubated for $18 \mathrm{~h}$ at $37^{\circ} \mathrm{C}$, allowing the strain to produce the enterotoxins. After incubation, CPS were enumerated according to ISO 6888-2:1999 [69]. The milk was also tested for the presence of SEs through an extraction step with dialysis concentration followed by qualitative detection using the two validated kits previously described. The liquid rennet (Caglificio Clerici, Cadorago Como, Italy) was added at $1 \mathrm{mg} / 10 \mathrm{~mL}$ concentration, according to the producers' instructions. The milk was maintained at $37^{\circ} \mathrm{C}$ for $1 \mathrm{~h}$ for the production of the curd that was eventually broken and transferred into a cheese mould and ripened for 8 days at $10^{\circ} \mathrm{C}$. At the end of the ripening, one portion of rind and one portion of core were tested for CPS and SEs. Rind and core extracted portions were also quantified for SE type A to E following the confirmatory method of the EURL for CPS [68].

\section{Results}

\subsection{SEs Genes and Molecular Typing}

Four of the strains resulted positive for one staphylococcal enterotoxin gene by mPCR: S. aureus ProNaCC1, ProNaCC2, ProNaCC4 and ProNaCC6 resulted positive for sed, see, sea, and seh, respectively. S. aureus strain ProNaCC5 resulted positive for seg and sei, and ProNaCC7 was positive for the genes sea, sed, selj, and ser (Table 3). The spa types and MLST resulted unique for each strain, except for the strains S. aureus ProNaCC1 and ProNaCC7, which belonged both to sequence type 8 (ST-8) but different spa-type (t2953 and t3802, respectively). All the strains resulted negative for the genes $m e c A$, mecC and $p v l$, and were, therefore, predicted as methicillin-sensitive S. aureus (MSSA).

Table 3. Molecular typing of the strains.

\begin{tabular}{cccc}
\hline Strain & Gene(s) & Spa-Type & MLST \\
\hline S. aureus ProNaCC1 & sed & $\mathrm{t} 2953$ & ST-8 \\
S. aureus ProNaCC2 & see & $\mathrm{t} 4461$ & ST-425 \\
S. aureus ProNaCC4 & sea & $\mathrm{t} 19075^{1}$ & ST-581 \\
S. aureus ProNaCC5 & seg/sei & $\mathrm{t} 164$ & ST-389 \\
S. aureus ProNaCC6 & seh & $\mathrm{t} 127$ & ST-1 \\
S. aureus ProNaCC7 & sea/sed/selj/ser & $\mathrm{t} 3802$ & ST-8 \\
\hline \multicolumn{4}{c}{}
\end{tabular}

In addition, the strain ProNaCC4 resulted a new spa type therefore, both the forward and reverse sequences of the gene spa were submitted to the server https://spa.ridom.de/index.shtml and a unique repeat succession was detected, assigned to the new spa type $\mathrm{t} 19075$. 


\subsection{Antimicrobial Susceptibility Testing}

The strains resulted sensible to all the antimicrobials tested in this study except for enrofloxacin for which all the strains were resistant at a concentration of $\leq 0.5 \mathrm{mg} / \mathrm{L}$. The strains ProNaCC1 and ProNaCC6 resulted resistant for benzylpenicillin at a concentration of $\geq 0.5 \mathrm{mg} / \mathrm{L}$ (Table 4). The MIC values for all the antimicrobials tested in this study are included in the Supplementary Material (Table S11).

Table 4. Detected resistance to antimicrobials among the strains included in this study.

\begin{tabular}{cccc}
\hline Strain & Antimicrobial & Class & MIC (mg/L) \\
\hline ProNaCC1 & Benzylpenicillin & Penicillins & $\geq 0.5$ \\
ProNaCC1 & Enrofloxacin & Fluoroquinolones & $\leq 0.5$ \\
ProNaCC2 & Enrofloxacin & Fluoroquinolones & $\leq 0.5$ \\
ProNaCC4 & Enrofloxacin & Fluoroquinolones & $\leq 0.5$ \\
ProNaCC5 & Enrofloxacin & Fluoroquinolones & $\leq 0.5$ \\
ProNaCC6 & Benzylpenicillin & Penicillins & $\geq 0.5$ \\
ProNaCC6 & Enrofloxacin & Fluoroquinolones & $\leq 0.5$ \\
ProNaCC7 & Enrofloxacin & Fluoroquinolones & $\leq 0.5$ \\
\hline
\end{tabular}

\subsection{General Features of Enterotoxigenic S. aureus}

The six enterotoxigenic $S$. aureus strains were whole-genome sequenced, and the draft assemblies ranged in size from 2.2 to $2.8 \mathrm{Mb}$ with a range of 2126 to $2747 \mathrm{CDs}$ (Table 5).

Table 5. Feature of the six sequenced genomes assembled with SPAdes.

\begin{tabular}{ccccccc}
\hline Feature & ProNaCC1 & ProNaCC2 & ProNaCC4 & ProNaCC5 & ProNaCC6 & ProNaCC7 \\
\hline Size $(\mathbf{b p})$ & $2,728,931$ & $2,782,905$ & $2,823,695$ & $2,260,169$ & $2,677,370$ & $2,607,693$ \\
Contigs $(>\mathbf{5 0 0}$ bp) & 19 & 45 & 54 & 15 & 9 & 14 \\
Contigs $>\mathbf{1} \mathbf{~ k b}$ & 19 & 40 & 35 & 11 & 8 & 14 \\
CD s ${ }^{1}$ & 2570 & 26,701 & 2747 & 2126 & 2473 & 2463 \\
G/C content & $32.53 \%$ & $32.80 \%$ & $32.78 \%$ & $32.71 \%$ & $32.66 \%$ & $32.61 \%$ \\
\hline \multicolumn{7}{c}{ Coding sequences $(C D s)$ assigned by PATRIC. }
\end{tabular}

The genomes were analysed for the virulence factors and, 111 unique genes were identified and classified into five categories: adherence $(n=31)$, exoenzymes $(n=29)$, genes involved in host immune system evasion $(n=7)$; iron uptake regulatory system $(n=8)$; secretion machinery factors and gene of toxins $(\mathrm{n}=36)$ (Figure 1$)$. 


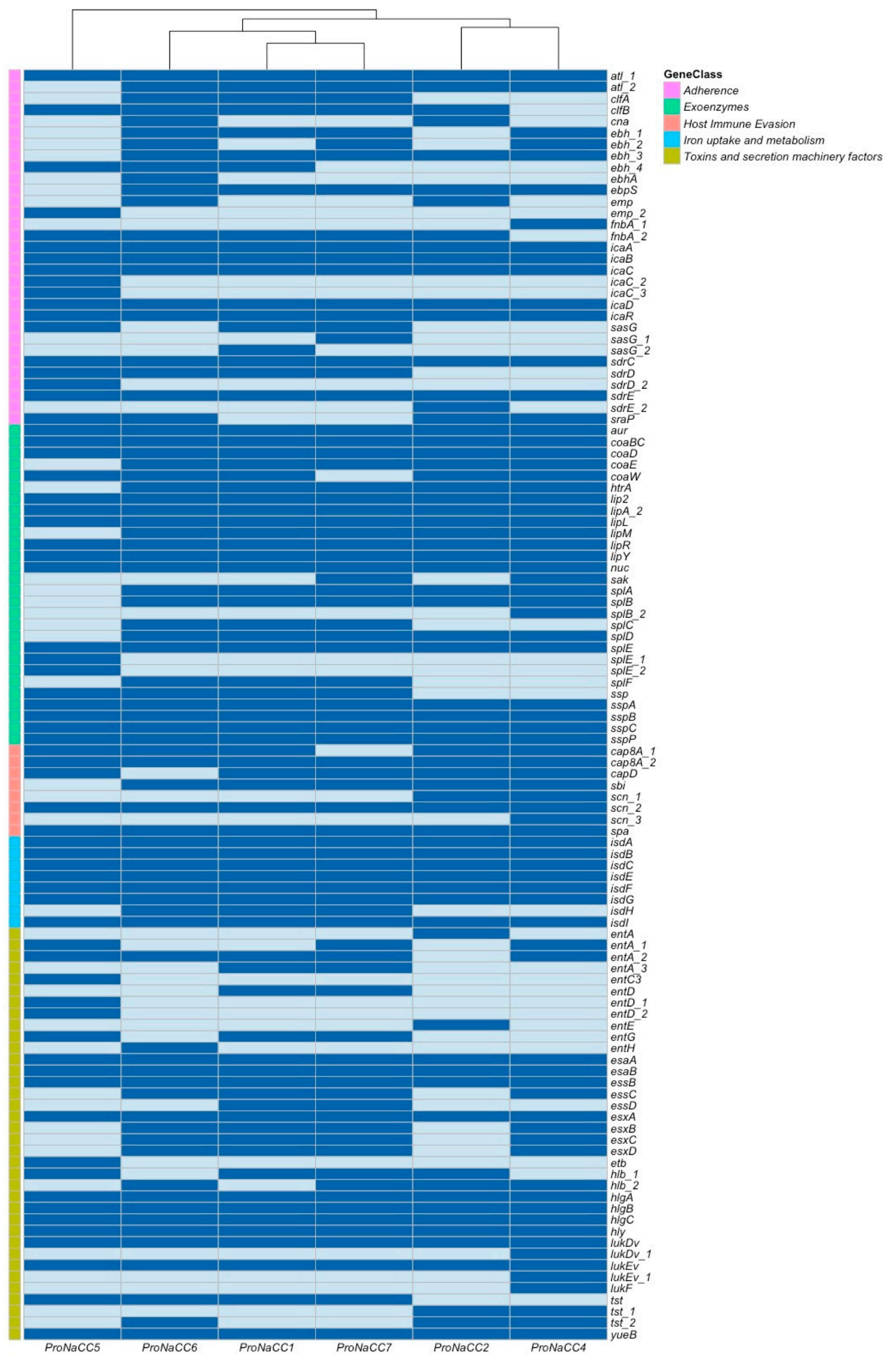

Figure 1. Heat map showing the profile of virulence factors (VFs) genes for the five enterotoxigenic S. aureus strains (dark blue: sequence detected; light blue: sequence not detected). 


\subsubsection{Adherence Factors}

In this study, $31 \mathrm{VFs}$ were annotated in the genome of the six enterotoxigenic $S$. aureus strains related to adherence factors. The genes identified in this category were: autolysin (atl), genes involved in binding proteins and adhesion ( $c n a, e b h, e b p S, e m p, f n b A, i c a A, i c a B, i c a C, i c a D, i c a R, s d r C, s d r D, s d r E$, $s d r I$ and $s r a P$ ), clumping factor genes (clfA, clfB), and cell wall surface anchor protein (sasG) (Figure 2).

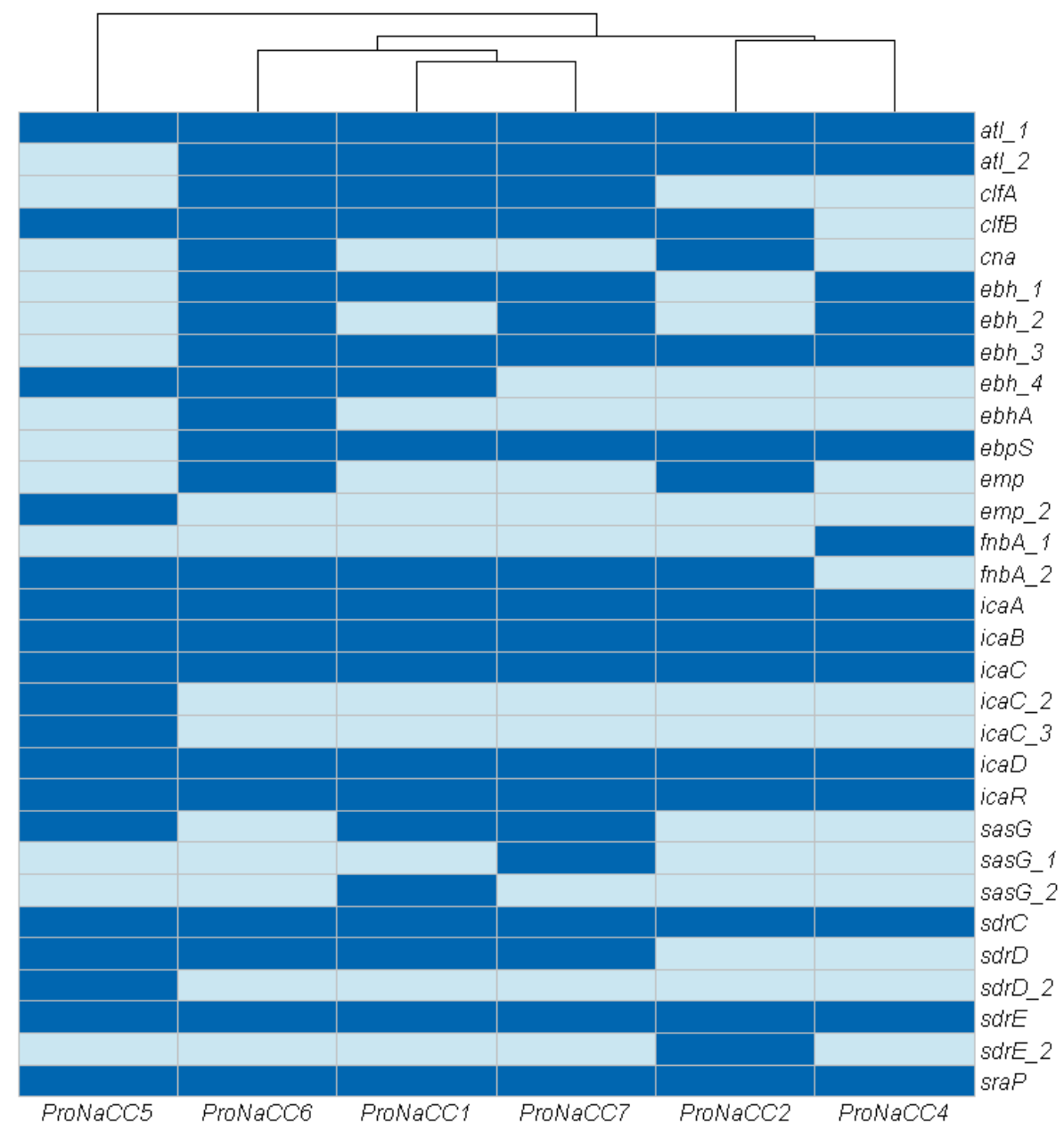

Figure 2. Heat map showing the adherence factors distribution among the six enterotoxigenic S. aureus strains (dark blue: sequence detected; light blue: sequence not detected).

The genes atl, icaA-C, $D, R$, and $s d r C, E$ were detected in all the strains; all the strains have at least one gene associated to bacterial proteins with the function of binding the major components of the extracellular matrix (ebh, ebhA, fnbA). The gene cna coding for collagen adhesin was detected only in the strains ProNaCC2 and ProNaCC6.

\subsubsection{S. aureus Exoenzymes}

In this class of VFs, 28 different genes were annotated, including the zinc metalloproteinase aureolysin (coa), serine protease family (splA-F), staphylokinase (sak), and other genes coding for enzymes (Figure 3). 


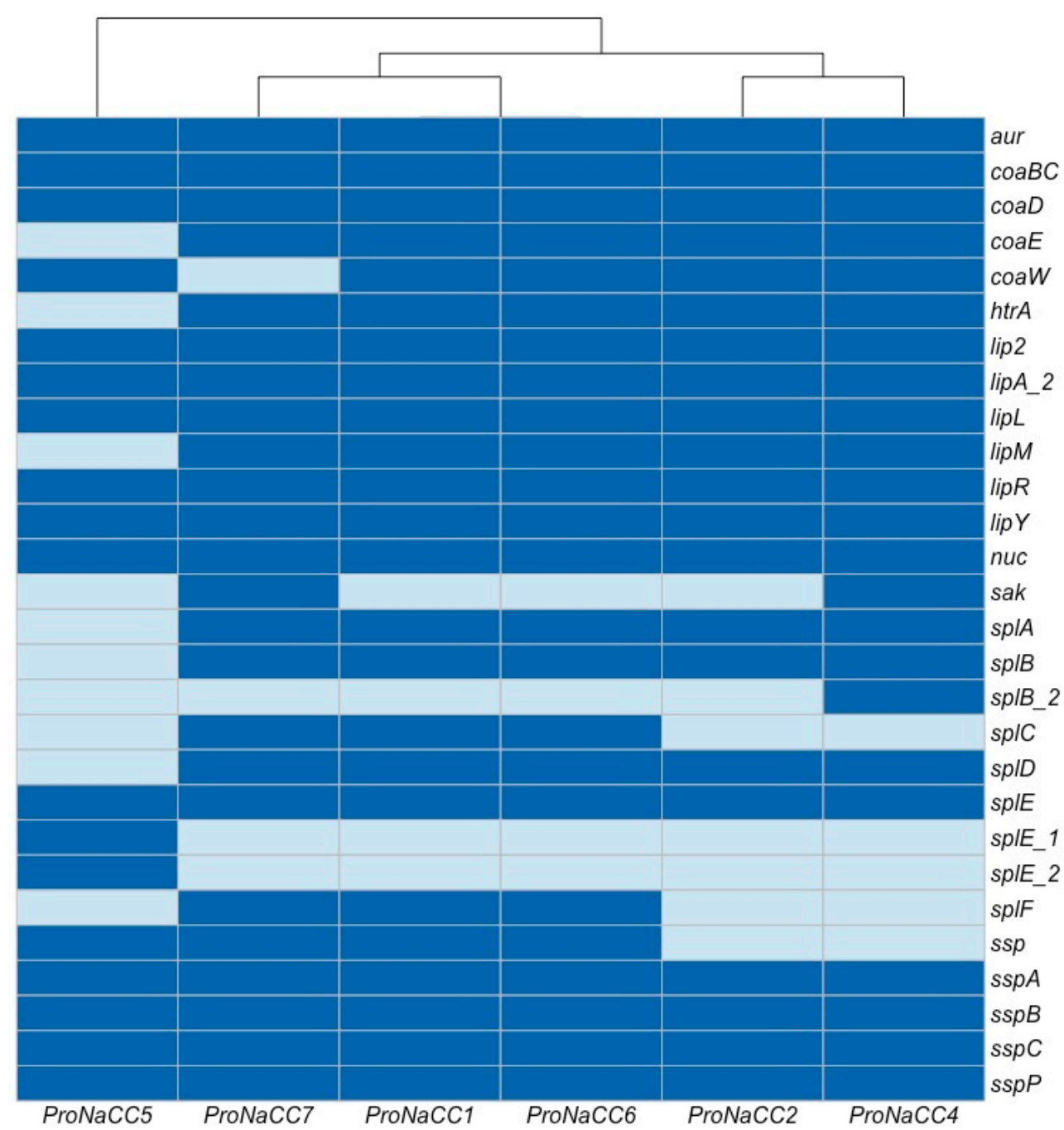

Figure 3. Heat map showing the exoenzymes genes among the six enterotoxigenic S. aureus strains (dark blue: sequence detected; light blue: sequence not detected).

All the genes coding for extracellular proteases were found in the six isolates, except for splD, which was not highlighted in the genome of the strain ProNaCC5 and splF on strains ProNaCC2, ProNaCC4 and ProNaCC5. All the other genes and at least one variant were found among all the genomes of the strain. Both the zinc metalloproteinase aureolysin (aur) and the thermonuclease (nuc) genes were found in all the strains.

\subsubsection{Genes Involved in Host Immune System Evasion}

In total, were detected seven genes of factors involved in host immune system evasion were detected, including the capsular synthesis (cap8A_1 and 2), immunoglobulin-binding protein (sbi) immunoglobulin G-binding protein A (spa) and the staphylococcal complement inhibitor (scn) (Figure 4). 


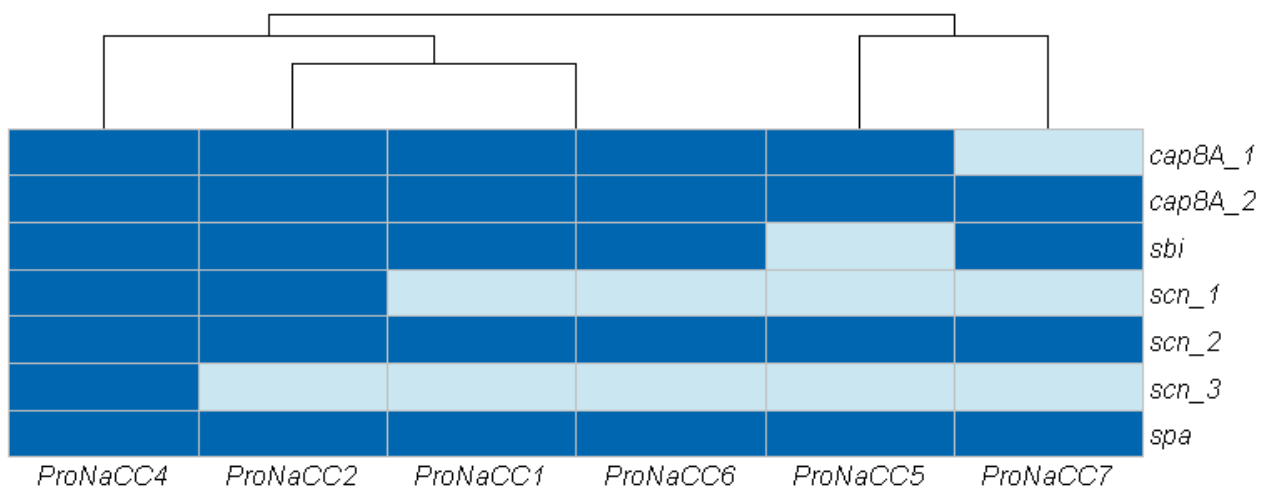

Figure 4. Heat map showing the genes involved in host immune system evasion among the six enterotoxigenic S. aureus strains (dark blue: sequence detected; light blue: sequence not detected).

The genes cap (cap8A_1-2) and scn (scn_1-3) and spa were detected on all the strains. The gene sbi was found, except in the strain ProNaCC5.

\subsubsection{Iron Uptake Regulatory System and Metabolism}

In this class, eight genes coding for iron-regulated surface determinant proteins (is $d A$, is $d B$, is $d C$, $i s d E$, isdF, isdG, isdH, and isdI) were identified (Figure 5).

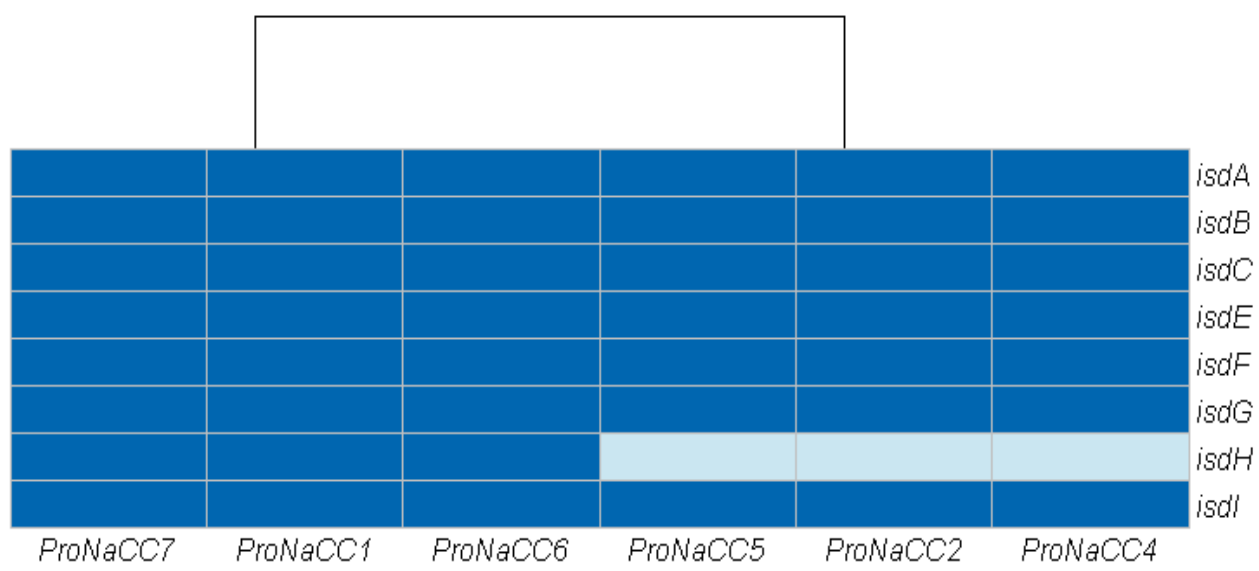

Figure 5. Heat map showing the genes coding for factors involved in the uptake of iron and metabolism among the six enterotoxigenic $S$. aureus strains (dark blue: sequence detected; light blue: sequence not detected).

The gene isdH is involved in the expression of the cell surface receptor IsdH for haemoglobin-haptoglobin complexes and was found in the genome of the strain ProNaCC1, ProNaCC6, and ProNaCC7; all the other genes were found in the genomes of the six strains.

\subsubsection{Toxins and Secretion Machinery Factors}

In this class the genes for toxins with haemolytic (hlb, hlg component $A-C, h l y)$ and leucotoxic activities $(l u k E v, l u k D v, l u k F)$, the genes involved in the secretion machinery (esaA/esxA/yueB, esaB/esxB/essB, $\operatorname{ess} C / \operatorname{es} x C$, essD/esxD), the toxic shock syndrome toxin (tst), the exfoliative toxin type $\mathrm{b}(e t b)$ and enterotoxins (ent $A$, ent $C$, ent $D$, ent $E$, ent $G$, ent $H$ ) were detected (Figure 6). 


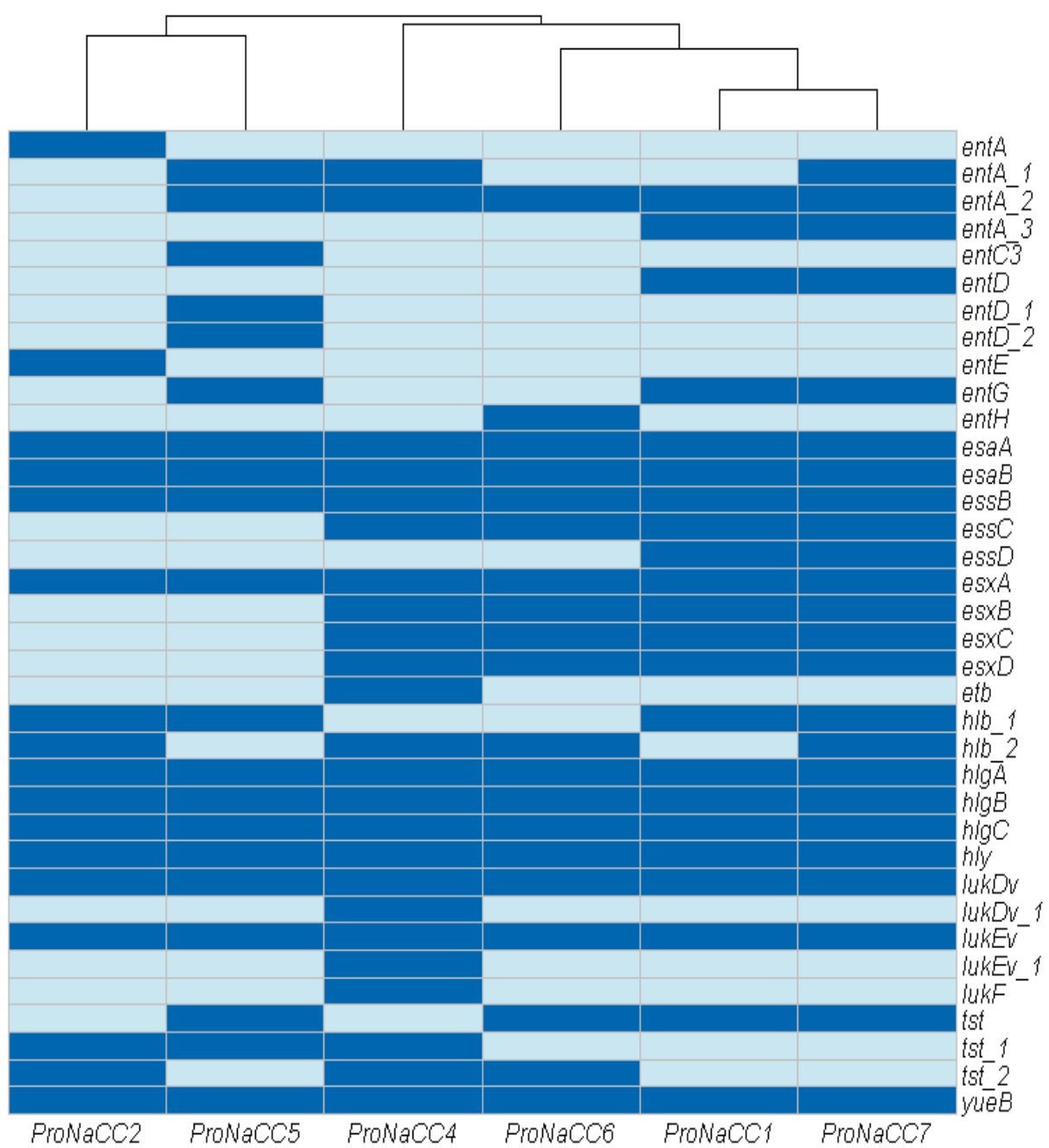

Figure 6. Heat map showing the genes coding for toxins and secretion machinery factors among the six enterotoxigenic $S$. aureus strains (dark blue: sequence detected; light blue: sequence not detected).

All the genes coding for the secretion machinery were detected in the strains ProNaCC1, ProNaCC6 and ProNaCC7. The strains ProNaCC6 and ProNaCC4 had all the genes for the secretion machinery, except the nuclease effector (essD) [70], the strains ProNaCC2 and ProNaCC5 had all except for the genes ess $D$ and ess $C$, which are required for the secretion of substrates including Es $x A$ and EsxB [71]. Among hemolysin genes, $\gamma$-hemolysins ( $h \lg A, h \lg B, h \lg C$ and $h l y)$ were identified in all the strains, including the $\beta$-hemolysin ( $h l b \_1$ ) which was found in all the strains except in the strain ProNaCC4 and ProNaCC6 where it was found the gene $h l b \_2$ was found, which is the coding gene for a truncated protein. Different genes related to components of Leucotoxins were found in all the strains, in particular, the genes $l u k E V$ and $l u k D V$ coding for the Leucotoxin LukEv and LukDV, respectively.

All the strains had at least one gene coding for enterotoxins either with intact sequences (ent $A$, ent $D$, ent $E$, ent $G$, ent $H)$ or for protein precursors (ent $A \_1$, ent $A \_2$, ent $A \_3$, entD_1, entD_2) and the exfoliative toxin type B (etb) was detected only in the strain ProNaCC4.

\subsubsection{Transcriptional Regulatory Elements}

The genes involved in the production of transcriptional regulatory elements $(n=39)$ were grouped in a sixth group (Figure 7). 


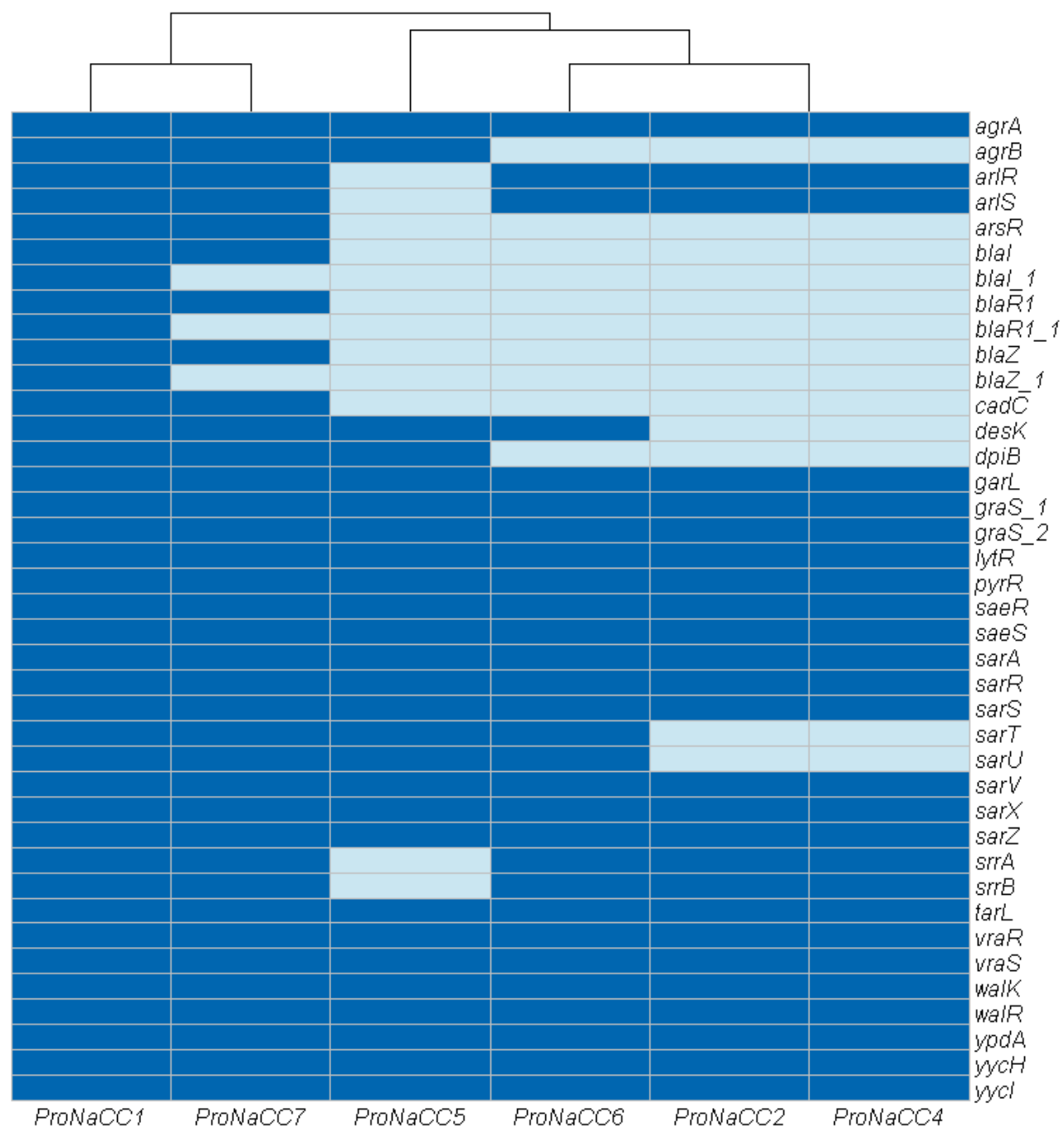

Figure 7. Heat map showing the genes coding for transcriptional regulator factors among the six enterotoxigenic S. aureus strains (dark blue: sequence detected; light blue: sequence not detected).

In this category, a total of 39 genes were identified and, selected for their involvement as transcriptional regulators of staphylococcal virulence factors the genes agr $A$, garL, graS_1, graS_2, lytR, pyrR, saeR, saeS, sarA, sarR, sarS, sarV, sarX, sarZ, srrA, srrB tarL, vraR, vraS walk, walR, ypdA, yycHm and $y y c I$ were detected in all the genomes. The genes involved in the arsenical resistance operon repressor $(\operatorname{ars} R)$ were detected in the strains ProNaCC1 and ProNaCC7, and cadmium resistance transcriptional regulatory protein $(\mathrm{cad} C)$ was detected in the strains ProNaCC1, ProNaCC5, ProNaCC6, and ProNaCC7, and the transcriptional repressor that constitutively blocks the expression of $\beta$-lactamase, bla family (genes blaI, blaI_1 blaR1,blaR_1 blaZ, blaZ_1) was detected in the strains ProNaCC1 and ProNaCC7. The genes coding the $S$. aureus two-component systems ( $\operatorname{srr} A$-srrB and arlR-arlS) involved in the global regulation of VFs, were detected in all the strains except in the genome of the strain ProNaCC5.

\subsection{Enterotoxin Insight}

Further analyses were performed for the gene coding staphylococcal enterotoxins. A novel database was built for ABRicate starting from amino acid sequences extracted from GenBank nucleotide and uniprot databases [72]. The sequences manually annotated (Swiss-prot) and un-reviewed enterotoxin variants (TrEMBL) were translated with the EMBOSS tool [73] and combined to build the final database (Supplementary Material Database S3), which included, in total, 99 sequences of staphylococcal enterotoxins and their variants. The strain ProNaCC1 was positive for the genes of the 
enterotoxins SED, SElJ, SER, SelX, and SElW; the strains ProNaCC2, ProNaCC4, and ProNaCC6 were positive for both the gene of the enterotoxins SEIX and SEIW and for the genes of SEE, SEA, and SEH respectively. The strain ProNaCC5 was positive for the genes of SEY, SElX, SEG, SEN, SEIU, SEI, SEM, and SEO, and the strain ProNaCC7 was positive for the gene coding for SED, SElJ, SER, SEA, SelW, and SEIX (Table 6).

Table 6. Staphylococcal enterotoxins found with the use of the database for ABRicate.

\begin{tabular}{|c|c|c|c|c|c|c|c|}
\hline Strain & Enterotoxin & Contig & $\begin{array}{l}\text { Sequence } \\
\text { Start }^{1}\end{array}$ & $\begin{array}{l}\text { Sequence } \\
\text { End }^{2}\end{array}$ & $\%$ Coverage ${ }^{3}$ & $\%$ Identity $^{4}$ & Reference $^{5}$ \\
\hline \multirow{5}{*}{ ProNaCC1 } & SED & 14 & 12,761 & 13,533 & 99.87 & 84.73 & UniProtKB-R9SA89 \\
\hline & SElJ & 14 & 14,428 & 15,212 & 97.64 & 83.95 & UniProtKB-O85217 \\
\hline & SER & 14 & 15,329 & 16,103 & 99.74 & 84.9 & UniProtKB-Q76LS8 \\
\hline & SElX & 3 & 249,399 & 250,007 & 100 & 84.24 & UniProtKB-G0Z026 \\
\hline & SEIW & 5 & 93,584 & 94,369 & 100 & 100 & GB-KX655710.1 \\
\hline ProNaCC2 & SEIW & 6 & 46,777 & 47,558 & 99.36 & 96.55 & GB-KX655711.1| \\
\hline \multirow{3}{*}{ ProNaCC4 } & SEA & 1 & 983 & 1744 & 98.57 & 81.15 & UniProtKB-P0A0L2 \\
\hline & SEIW & 3 & 200,805 & 201,585 & 99.36 & 96.16 & GB-KX655711.1 \\
\hline & SElX & 7 & 89,367 & 89,975 & 100 & 84.4 & UniProtKB-G0Z026 \\
\hline \multirow{5}{*}{ ProNaCC5 } & SElY & 2 & 58,778 & 59,440 & 100 & 84.77 & UniProtKB-A0A0K2S2V0 \\
\hline & SEIU & 9 & 15,630 & 16,397 & 98.08 & 84.42 & UniProtKB-Q6XXM3 \\
\hline & SEI & 9 & 16,560 & 17,279 & 99.17 & 87.5 & UniProtKB-O85383 \\
\hline & SEM & 9 & 17,320 & 18,033 & 99.58 & 85.01 & UniProtKB-A0A0H3K005 \\
\hline & SEO & 9 & 18,317 & 19,096 & 100 & 87.82 & UniProtKB-A0A0H3JS76 \\
\hline \multirow{3}{*}{ ProNaCC6 } & SElW & 1 & $1,068,149$ & $1,068,933$ & 99.87 & 97.84 & GB-KX655711.1 \\
\hline & SElX & 2 & 96,391 & 96,999 & 100 & 82.92 & UniProtKB-G0Z026 \\
\hline & SEH & 5 & 98,979 & 99,700 & 99.86 & 86.29 & UniProtKB-P0A0M0 \\
\hline \multirow{4}{*}{ ProNaCC7 } & SED & 11 & 6058 & 6830 & 99.87 & 84.73 & UniProtKB-R9SA89 \\
\hline & SElJ & 11 & 7725 & 8509 & 97.64 & 83.95 & UniProtKB-O85217 \\
\hline & SER & 11 & 8626 & 9400 & 99.74 & -84.9 & UniProtKB-Q76LS8 \\
\hline & SEA & 2 & 88,812 & 89,579 & 99.61 & 85.81 & UniProtKB-P0A0L2 \\
\hline
\end{tabular}

\footnotetext{
${ }^{1}$ Sequence Start: start coordinate in the sequence; ${ }^{2}$ Sequence End: end coordinate in the sequence; ${ }^{3} \%$ Coverage: proportion of gene covered; $4 \%$ Identity: proportion of exact nucleotide matches; ${ }^{5}$ Reference: the genomic source of the sequence (UniProtKB: UniProt Knowledgebase; GB: GenBank nucleotide reference number.
}

The genomes were submitted to the PHASTER web server for the identification of prophage sequences and the output was tested for the presence of SEs with the database developed for ABRicate. The intact prophages regions and the hypothetical proteins sequences associated with prophages were considered in the study for the analysis of SEs similarities. According to the score assigned by the software, 20 of the prophages most common regions within the six enterotoxigenic genomes were identified: three regions resulted intact, 13 regions were incomplete, and four were questionable (Table S4).

The intact prophage most common regions were identified on the strain ProNaCC2 $(\Phi N 315$, ФSa119), ProNaCC4 (ФN315, ФBU01), and ProNaCC7 (ФN315, ФSa119, ФNM3, ФBU01). The phage regions included the gene for the staphylococcal enterotoxin type $\mathrm{E}$ in the strain ProNaCC2 and the gene for the staphylococcal enterotoxin type A in the strains ProNaCC4 and ProNaCC7 (Table 7). 
Table 7. Detection of mobile genetic elements and the presence of staphylococcal enterotoxins genes and percentage of coverage to the reference sequences.

\begin{tabular}{|c|c|c|c|c|c|c|c|c|c|c|}
\hline Strain & SaPI1 $^{1}$ & $\mathrm{SaPI}^{2}$ & $\mathrm{SaPI}^{3}$ & $\mathrm{SaPI}^{4}$ & SaPI3 $^{5}$ & SaPI (fhuD) ${ }^{6}$ & SaPIbov $^{7}$ & Prophage (Gene SE) & Plasmid pLUH02 ${ }^{8}$ & Plasmid pSK67 $^{9}$ \\
\hline ProNaCC1 & n.d. & $100 \%$ & $100 \%$ & n.d. & n.d. & n.d. & n.d. & n.d. & $98.11 \%$ (sed, selj ser) & n.d. \\
\hline ProNaCC2 & $1.46 \%$ & $100 \%$ & n.d. & $48.07 \%$ & $100 \%$ & n.d. & n.d. & ФN315, ФSa119 (see) & n.d. & n.d. \\
\hline ProNaCC4 & n.d. & n.d. & n.d. & n.d. & $100 \%$ & $0.40 \%$ & $25.11 \%$ & ФN315, ФBU01 (sea) & n.d. & n.d. \\
\hline ProNaCC5 & n.d. & $100 \%$ & n.d. & n.d. & n.d. & $23.98 \%$ & $0.44 \%$ & n.d. & n.d. & n.d. \\
\hline ProNaCC6 & n.d. & $100 \%$ & $100 \%$ & n.d. & n.d. & n.d. & $0.44 \%$ & n.d. & n.d. & n.d. \\
\hline ProNaCC7 & n.d. & $100 \%$ & $100 \%$ & n.d. & n.d. & n.d. & n.d. & $\begin{array}{c}\text { ФN315, ФSa119, } \\
\text { ФNM3, ФBU01 (sea) }\end{array}$ & n.d. & $85.14 \%$ (sed, selj ser) \\
\hline
\end{tabular}

${ }^{1}$ Reference sequences were obtained from GenBank. Accession number U93688.2 ${ }^{2}$ CP000046.1, region 1,922,358-1,922,544; ${ }^{3}$ CP000046.1, region 2,074,546-2,075,382; ${ }^{4}$ CP000046.1, region 903,332-906,333; ${ }^{5}$ CP000046.1, region 397,869-398,153; ${ }^{6}$ AB983199.1; ${ }^{7}$ AF217235.1; ${ }^{8}$ NZ_LJBK01000031.1; ${ }^{9}$ GQ900447.1; n.d.: not detected. 
The genetic surrounding of the tst locus was further investigated for the genomic localisation, because this virulence factor can be associated with SaPIs, which includes the genes for specific staphylococcal enterotoxins. The database developed for this analysis was built for ABRicate and had sequences of 74 SaPIs included the specific sequences of SEs found in these loci (Supplementary Material Database S5). The analysis showed that all six strains contained the SaPI3 similar to the SaPI described in Staphylococcus aureus subsp. aureus COL [74] with a 100\% coverage for specific genomic portions with an identity at the nucleotide level between $94.2 \%$ and $100 \%$ to the reference sequence. The other SaPIs with an identity percentage higher than 95.0 had a percentage of coverage less than or equal to 48.07 at the nucleotide level (Table S6). The SaPI1 (ref U93688.2) was identified in the genome of the strain ProNaCC2 with a percentage of coverage of 1.46 at the nucleotide level. A portion of the SaPI (fhuD) (ref AB983199.1) was found in the genome of PronaCC4 and ProNaCC5 with a coverage of $0.4 \%$ and $23.98 \%$, respectively. The SaPIbov (ref. AF217235.1) was found in the genome of the strains ProNaCC4 with a percentage of coverage of 25.11 at the nucleotide level and at $0.44 \%$ in the genome of the strains ProNaCC5 and ProNaCC6. Those genomic loci were analysed for the detection of the SEs gene sequences, but intact sequences were not found (Table 7).

In total, $4456 \mathrm{~S}$. aureus plasmid complete sequences were used to build the novel ABRicate database (Supplementary Material Database S7). The database was filtered for the presence of staphylococcal enterotoxin sequences using the database developed in this study (Supplementary Material Database S3). The plasmids positive for SEs gene sequences were 186; from this group, the plasmids with the presence of enterotoxin genes with a percentage of coverage greater than or equal to 95.00 at the nucleotide level with the reference sequences were selected. In this selection, were found the gene sequences of the enterotoxin sed, selj, ser, ses and set, confirming the plasmid location of these genes [23]. The sequence of the plasmid pLUH02 [75] (ref. NZ_LJBK01000031.1) was found almost intact $(98.11 \%$ coverage and $99.78 \%$ identity at the nucleotide level) in the genome of the strain ProNaCC1 (Table S8). The sequence of the plasmid pSK67 (ref. GQ900447.1) was found in the genome of the strain ProNaCC7 with an identity at the nucleotide level of $99.83 \%$ but a coverage lower than the threshold $(85.14 \%)$. Both the plasmid sequences tested for the enterotoxin database resulted positive for the sequences of sed, selj, ser (Figure 8).

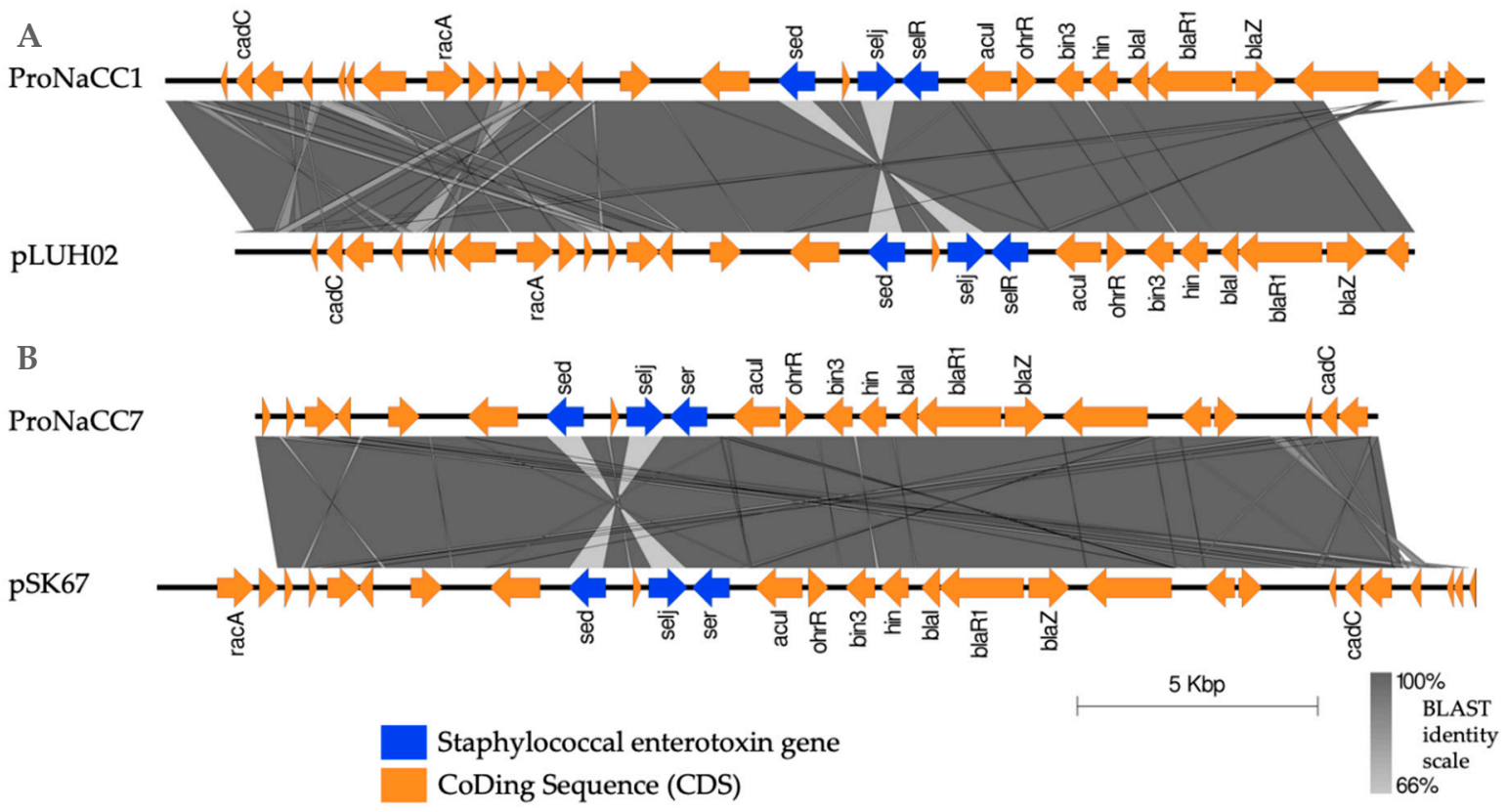

Figure 8. Comparison of plasmidic regions detected in the genome of the strains ProNaCC1 (A) and ProNaCC7 (B) with the plasmids pLUH02 and pSK67. The regions included the enterotoxin and enterotoxin-like genes and the coding sequences (CDS) detected in the regions. 


\subsection{Antimicrobial Resistance Genes}

The transcriptional regulator gene $m g r A$ was the only regulatory factor involved in multidrug resistance identified among the study strains. The gene was present in all six strains with sequence identity at the nucleotide level of $100 \%$ relative to the NC_002745 reference sequence (Figure 9). The gene $m g r A$ is a regulator factor for nor $A$ and tet 38 which are the antibiotic resistance-encoding gene for quinolone and tetracycline, respectively [76], and were found in all six strains. The sequence identity at the nucleotide level of the gene nor $A$ was ranging between $76.01 \%$ and $76.23 \%$ relative to the AY566250 reference sequence. The gene tet 38 had a sequence identity at the nucleotide level ranging between $98.67 \%$ and $99.85 \%$ relative to the AY825285 reference sequence. In addition, the genes $\operatorname{arl} R$ and $\operatorname{arlS}$, which are involved in the cascade reaction for the nor $A$ activation, were found in all the strains except the strain ProNaCC5. The penicillin resistance gene blaZ was identified in the strains ProNaCC1 and ProNaCC7. The gene was present in both the strains with a sequence identity at the nucleotide level of 96.45 relative to the CP000732 reference sequence. The fusidic acid resistance gene fus $C$ was found only in the strain ProNaCC6 with a sequence identity of 100\% with the NC_002953 reference sequence.

\begin{tabular}{|l|l|l|l|l|l|l|l|l|l|l|}
\cline { 2 - 10 } \multicolumn{1}{c|}{} & arlR & arlS & fosB3 & fusC & mepA & mepR & mgrA & norA & blaZ & tet38 \\
\hline ProNaCC1 & & & & & & & & & & \\
\hline ProNaCC2 & & & & & & & & & & \\
\hline ProNaCC4 & & & & & & & & & \\
\hline ProNaCC5 & & & & & & & & & \\
\hline ProNaCC6 & & & & & & & & & \\
\hline ProNaCC7 & & & & & & & & & \\
\hline
\end{tabular}

Figure 9. Genes related to antimicrobial resistance and their distribution among the six strains. The heatmap depicts the presence (green) or absence (grey) of genes. When mutations, such as internal deletions, were identified, they were highlighted in yellow. arlR: response regulator ArlR gene; arlS: signal transduction histidine-protein kinase ArlS gene; fosB3: metallothiol transferase FosB gene; fusC: fusidic acid resistance gene; терA: multidrug resistance efflux protein MepA gene; mepR upstream repressor of $m е p A$ gene; $m g r A$ : transcriptional regulator gene for nor $A$, nor $B$, and tet38; nor $A$ : quinolone resistance protein gene; blaZ: $\beta$-lactamase penicillin resistance gene; tet38: tetracycline efflux pump gene.

The lanthionine-containing peptide antibiotic (lantibiotic) gene (bsaA2) [77], was the only bacteriocin found among the six enterotoxigenic $S$. aureus genomes that had a sequence identity at the nucleotide level of $100 \%$ with the reference sequence of the bagel 3 database. The sequence was found in the genome of the strains ProNaCC1, ProNaCC6, and ProNaCC7. The second highest percentage identity bacteriocin gene was the delta-hemolysin ( $h l d)$, which had $80.00 \%$ of identity with the reference sequence, and it was found in the genome of ProNaCC1, ProNaCC4, ProNaCC5, and ProNaCC7. In total, 38 other bacteriocins (Table S9) with a sequence identity at the nucleotide level were found to range between $3.33 \%$ and $54.55 \%$.

\subsection{Core Genomes}

A pan-genome of 5651 genes was generated from the six enterotoxigenic strains and 29 enterotoxigenic strains reported in the literature (Table S2). The total number of core genes was 1364, which represents the number of genes that are shared in a percentage higher than $99 \%$ among the six strains. Based on the output of Roary, insight into their pan-genomic property was also gained. In Figure 10, presents the tree constructed by clustering strains based on accessory genes and the matrix plot, which denotes the presence and absence of every gene over all strains by blue and white, respectively. Figure 10 presents the reported the geographic locations (Australia, Denmark, France, Italy, Japan, Russian Federation, Switzerland, United Kingdom), isolation sources (Staphylococcal Food 
Poisoning event, milk, clinical and food samples), and the enterotoxins identified with the ABRicate database for each strain.

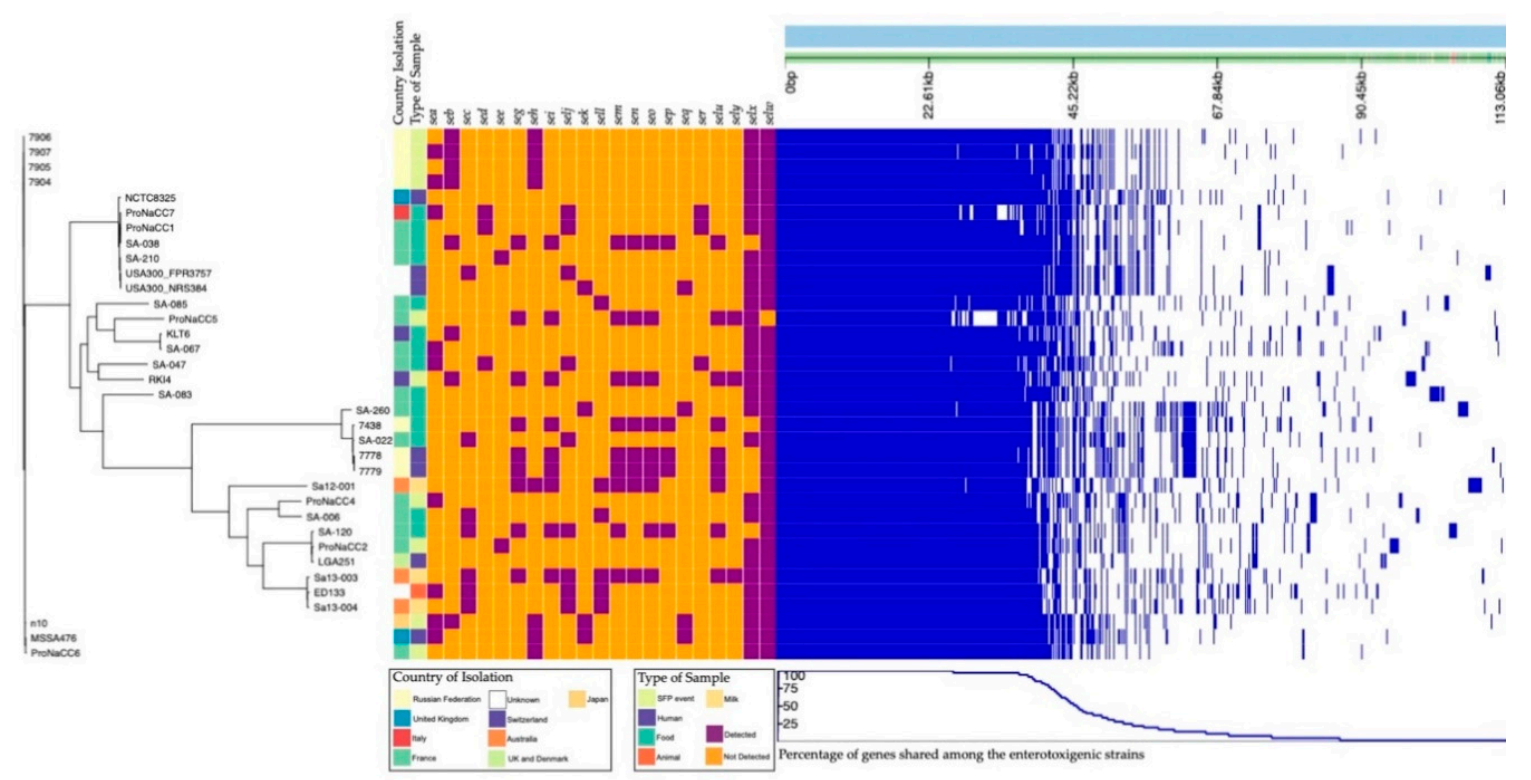

Figure 10. Pan-genomic analysis of the 35 enterotoxigenic strains. On the left side is the phylogenetic tree of the strains included in this study. On the central heatmap is the the geographical location of isolation and sources (colour legend in the picture). The detection of the gene coding for enterotoxins is reported as presence and absence with the colours purple and orange respectively.

At least two genes coding for staphylococcal enterotoxins were detected in all the genomes included in the analysis. The genes selx and selw were the most prevalent among the 39 strains; nevertheless, no correlation was found between the country of isolation and origin of the samples. The functional annotation of the six-enterotoxigenic S. aureus pan-genome was $66.2 \%$ of the COGs database with known functions of the total pan-genome (Figure 11).

The pangenome of the six enterotoxigenic $S$. aureus was assembled to highlight the genetic and pathogenic diversity of the strains, and the locations of the SE genes compared to the core genome were validated. The gene of the staphylococcal enterotoxin-like $\mathrm{x}$ gene $(\operatorname{sel} x)$ was detected in the core genome, as already described, along with the gene selw, in almost all the 35 strains included in the pangenome study. However, the genes coding for enterotoxins were detected mostly in specific accessory genomic regions, demonstrating the importance and the role of these genomic structures for the evolution of S. aureus as foodborne pathogens. 


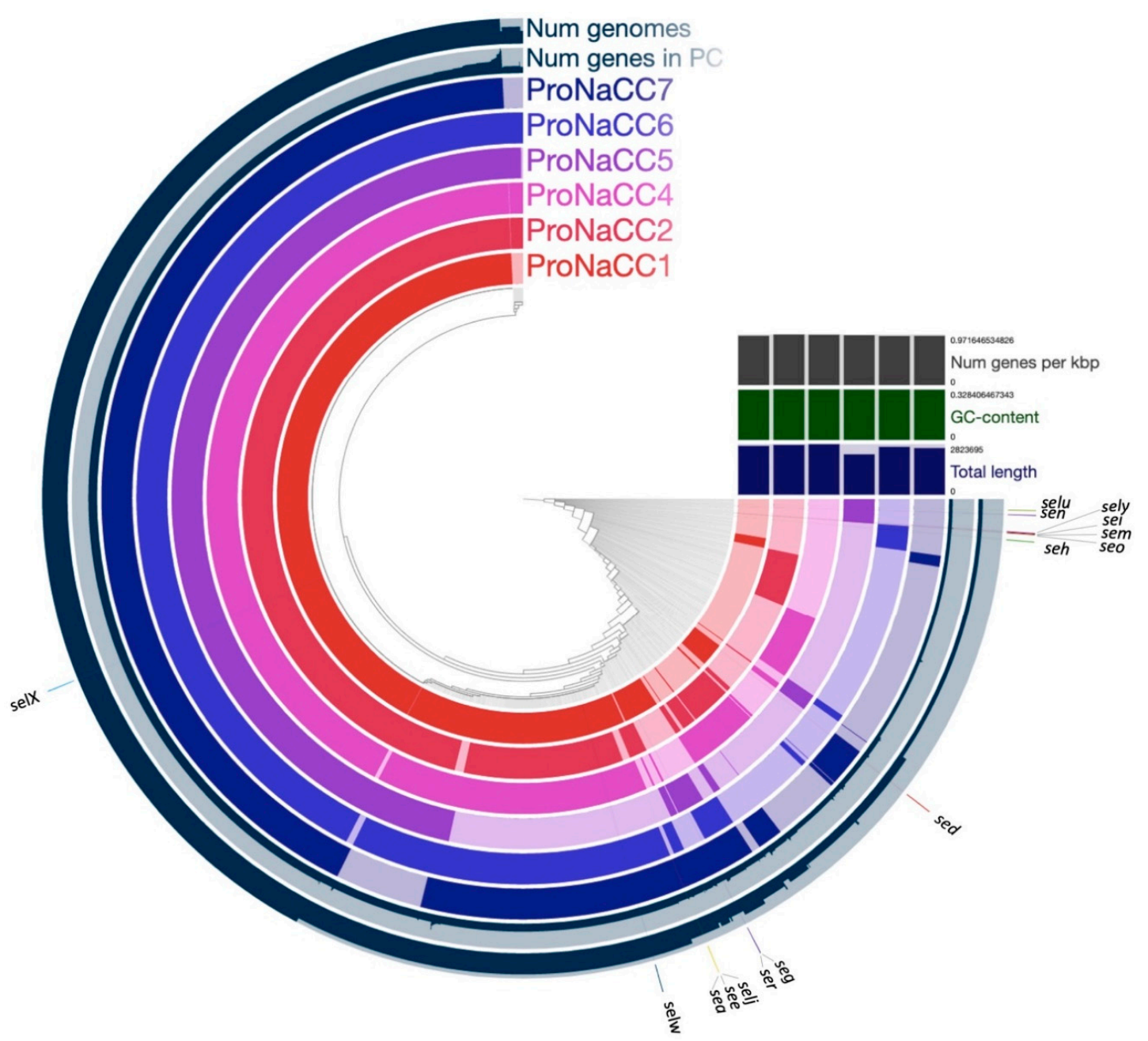

Figure 11. Clusters of Orthologous Groups (COG) function of the six enterotoxigenic S. aureus pan-genomes. The figure presents the location of the staphylococcal enterotoxin genes and their position. Num genomes: the bar represent the number of genomes per cluster; Num genes in PC: the graph represent the number of genes in protein clusters; GC-content: guanine-cytosine content. The genes of the enterotoxins are presented in the short form: sea, sed, see, seg, she, sei, selj, sem, sen, seo, ser, selu, selw, selx, sely.

\subsection{SEs Production and Naturally-Contaminated Cheeses}

The strains ProNaCC1, ProNaCC2 and ProNaCC4 produced SED, SEE and SEA in $0.85 \% \mathrm{NaCl}$ solution respectively. The strains ProNaCC5 and ProNaCC6 resulted negative for the production of toxins in vitro and the strain ProNaCC7 produced both SEA and SED. The milk used in this study had a fat content of $36.0 \mathrm{~g}$ per litre, $49.0 \mathrm{~g}$ of carbohydrates per litre, $32.0 \mathrm{~g}$ of proteins per litre, and $0.9 \mathrm{~g}$ of $\mathrm{NaCl}$ per litre as the average content declared by the producer. Four batches of the milk incubated with the enterotoxigenic strains $(18 \mathrm{~h})$ resulted positive at both qualitative methods for SEs detection (Table 8) for the enterotoxins detectable with the available methods. The ripened wheels were subsampled on peripheral (rind portion) and internal (core portion) sampling area and resulted positive to qualitative methods. The concentration of the toxins in the core ranged from $1.833 \mathrm{ng} / \mathrm{g}$ for the SEA for the batch number 6 (ProNaCC7) and $9.126 \mathrm{ng} / \mathrm{g}$ for toxin type E detected in cheese number 2 (inoculated with strain ProNaCC2); the concentration in the peripheral part (rind) ranged from 1.849 $\mathrm{ng} / \mathrm{g}$ for SEA in cheese batch number 6 and $8.419 \mathrm{ng} / \mathrm{g}$ for SEE in cheese batch number 2 . 
Table 8. Enterotoxins production in vivo: immunochemical qualitative and quantitative methods.

\begin{tabular}{|c|c|c|c|c|c|}
\hline $\begin{array}{l}\text { Batch and } \\
\text { Strain }\end{array}$ & $\begin{array}{l}\text { SEs Genes } \\
\text { Detected }\end{array}$ & $\begin{array}{l}\text { Milk after } 18 \mathrm{~h} \\
\text { Incubation }\end{array}$ & Sampling Area & $\begin{array}{l}\text { Qualitative } \\
\text { Methods }\end{array}$ & $\begin{array}{l}\text { Amount of Protein } \\
\text { Produced [SE] (ng/g } \\
\text { of Cheese) }\end{array}$ \\
\hline \multirow{2}{*}{ 1-ProNaCC1 } & \multirow{2}{*}{$\mathrm{sed} / \mathrm{ser} / \mathrm{selj}$} & \multirow{2}{*}{ pos } & Core & pos & {$[\mathrm{SED}]=7.966$} \\
\hline & & & Periphery & pos & {$[\mathrm{SED}]=6.607$} \\
\hline \multirow{2}{*}{ 2-ProNaCC2 } & \multirow{2}{*}{ see } & \multirow{2}{*}{ pos } & Core & pos & {$[\mathrm{SEE}]=9.126$} \\
\hline & & & Periphery & pos & {$[\mathrm{SEE}]=8.419$} \\
\hline \multirow{2}{*}{ 3-ProNaCC4 } & \multirow{2}{*}{ sea } & \multirow{2}{*}{ pos } & Core & pos & {$[\mathrm{SEA}]=2.760$} \\
\hline & & & Periphery & pos & {$[\mathrm{SEA}]=2.648$} \\
\hline \multirow{2}{*}{ 4-ProNaCC5 } & \multirow{2}{*}{$\mathrm{seg} / \mathrm{sei}$} & \multirow{2}{*}{ neg } & Core & neg & neg \\
\hline & & & Periphery & neg & neg \\
\hline \multirow{2}{*}{ 5-ProNaCC6 } & \multirow{2}{*}{ seh } & \multirow{2}{*}{ neg } & Core & neg & neg \\
\hline & & & Periphery & neg & neg \\
\hline \multirow{4}{*}{ 6-ProNaCC7 } & \multirow{4}{*}{ sea/sed/selj/ser } & pos & Core & pos & {$[\mathrm{SEA}]=1.833$} \\
\hline & & & & & {$[\mathrm{SED}]=7.578$} \\
\hline & & pos & Periphery & pos & {$[\mathrm{SEA}]=1.849$} \\
\hline & & & & & {$[$ SED] $=7.841$} \\
\hline
\end{tabular}

${ }^{\mathrm{a}}$ Data are the means of two biological repetitions.

The six batches of spiked milk resulted positive for CPS after $18 \mathrm{~h}$ of enrichment at $37^{\circ} \mathrm{C}$ with a concentration between $2.1 \times 10^{7}$ and $1.1 \times 10^{8} \mathrm{CFU} / \mathrm{g}$. The fresh cheeses were tested for CPS after $3 \mathrm{~h}$ of ripening (sweating stage) and their number was between 2.5 and $5.6 \times 10^{8} \mathrm{CFU} / \mathrm{g}$ (Table 9).

Table 9. Enterotoxins production in vivo: immunochemical qualitative and quantitative methods.

\begin{tabular}{ccc}
\hline Batch and Strain & $\begin{array}{c}\text { CPS in Spiked Milk 18 h } \\
\text { Enrichment (CFU/g) }\end{array}$ & $\begin{array}{c}\text { CPS in Fresh Cheese after } \\
\text { Sweating (CFU/g) }\end{array}$ \\
\hline 1-ProNaCC1 & $2.1 \times 10^{7}$ & $2.8 \times 10^{8}$ \\
2-ProNaCC2 & $5.3 \times 10^{7}$ & $2.5 \times 10^{8}$ \\
3-ProNaCC4 & $1.1 \times 10^{8}$ & $2.9 \times 10^{8}$ \\
4-ProNaCC5 & $9.2 \times 10^{7}$ & $5.6 \times 10^{8}$ \\
5-ProNaCC6 & $9.2 \times 10^{7}$ & $2.5 \times 10^{8}$ \\
6-ProNaCC7 & $3.8 \times 10^{7}$ & $3.2 \times 10^{8}$ \\
\hline
\end{tabular}

\section{Discussion}

In this study, six enterotoxigenic strains of $S$. aureus were whole-genome sequenced and the distribution of $110 \mathrm{VFs}$ and 39 genes involved in the production of transcriptional regulatory elements was determined. The strains resulted positive for the staphylococcal enterotoxins genes commonly reported as a causative agent of food poisoning and the associated computational analysis added a detailed characterisation and identification of further enterotoxin genes that complete the comprehensive portraits of the strains presented. Previous studies reported food poisoning outbreaks caused by enterotoxigenic $S$. aureus, and they were focused on the outbreak investigation, strain genotyping and characterisation of produced SEs [25,27-29,78,79]. Other studies included the identification of different VFs of $S$. aureus enterotoxigenic strains isolated from foods and from SFP outbreaks by PCR $[80,81]$ with the use of microarray-based methods [82] and analysing the whole genome sequences $[83,84]$. However, these studies focused on the presence of few VFs or specific staphylococci related to host [85]. In this study, 149 genes were detected in the genome of the enterotoxigenic strains and the genes related to staphylococcal enterotoxins were further characterised with the use of dedicated databases developed in this study. The VFs were grouped into six functional categories and their distribution was determined in the six enterotoxigenic strains. In addition, the strains with other 29 enterotoxigenic strains reported in the literature were used for constructing the 
pan-genome of enterotoxigenic S. aureus, highlighting the genomic location of the enterotoxins and their role in the evolution of its genome.

The virulence of $S$. aureus is facilitated by the attachment to the host cell and is mostly mediated by adhesins [86]. In the genome of the six enterotoxigenic $S$. aureus strains 31 genes coding for proteins that mediate the adherence to damaged tissues, extra-cellular matrix, and the surface of cells were annotated. The intercellular adhesion (ica) locus consists of different genes (icaA, icaB, icaC, icaD) and the promotor icaR, which are involved in the biofilm formation initiated by atl $[87,88]$. In other studies, the strains ica-positive were isolated in both the food and clinical environment, but their presence was not always associated with the production of biofilm [89]. The database included other genes involved in the formation of biofilms, i.e., the accumulation-associated protein gene (aap) and the biofilm-associated protein (bap), but none of the six enterotoxigenic strains resulted positive. Other genes associated with adhesion, invasion, and evasion were found in all the strains, in particular, the genes $s d r C$ and $s d r E$, which were reported in clinical isolates [90,91].

Enterotoxigenic $S$. aureus can produce exoenzymes which are active against the immune system and have a proteolytic effect on complex molecules. The genes coding for thermonuclease $(n u c)$, aureolysin (aur), staphylocoagulase (coa), lipase (lip), and extracellular matrix protein-binding protein $(s s p)$ were found in all the strains; this result was demonstrated in other studies for non-aureus staphylococci, where these genes were the most reported among this group of VFs [86,92]. The gene for HtrA surface protease was found in all the strains except the strain ProNaCC5. The protein is involved in the virulence of many pathogens, and it has a role in stress resistance and bacterial survival [93]. The genes coding for serine protease-like proteins (splA-F) are organized in an operon and exhibit proteolytic activity [94]. At least one gene of these exoenzymes was found in all the strains and have not been described in enterotoxigenic S. aureus isolates yet. Only the strains ProNaCC4 and ProNaCC7 had the gene for staphylokinase (also known as SAK) (sak). This virulence factor is located in different prophages, including the prophages carrying the genes for the enterotoxin SEA [23], which was found in both the strains.

The virulence of $S$. aureus is related to the ability to evade the host immune system and to produce capsular polysaccharides, including the enterotoxigenic strains [95]. Among this class, the genes located in the immune evasion cluster ( $s b i, s c n$ and spa) were detected; the presence of these genes can be an advantage for pathogenesis of these enterotoxigenic strains as suggested in different studies where the genes were considered highly specific for staphylococcal isolates of human origin, including methicillin-resistant and methicillin-sensitive S. aureus [96].

The VFs involved in the uptake of iron and metabolism found among the six enterotoxigenic strains were part of the iron-regulated surface determinants (isd). This group of genes is encoded by five transcriptional units including is $d A$, is $d B$, is $d C-D-E-F-s r t B-i s d G$, is $d H$, and isdI [97], which were found in all the six enterotoxigenic strains except the gene $i s d H$ that was not detected in the strains ProNaCC2, ProNaCC4 and ProNaCC5. The accessory gene regulator agr is a S. aureus quorum-sensing system involved in the control of different VFs including toxins [98]. This system is a multicomponent signal transduction system that is able to regulate the enterotoxin production through a complex network of pathways $[99,100]$. The gene agr was detected in all the strains within the genes for SarA protein family, SrAB protein, and SaeRS two-component system that controls the expression of several virulence factors with both positive and negative effects. The genes coding for the member of the two-component regulatory system WalK/WalR, VraS/VraR and the genes of the YycH family protein were found in all the six enterotoxigenic strains. These factors are involved in the control of autolysis, biofilm formation and cell wall metabolism [101].

The toxins produced by S. aureus are different molecules that can be grouped in hemolysins, leukocidins/leukotoxins, toxic shock syndrome toxin, exfoliative toxins, exotoxins and enterotoxins. In addition, the genes involved in the secretion system were included in this group of genes and all the six strains contained at least one of them (esaA/es $x A / y u e B, \operatorname{esa} B / \operatorname{es} x B / \operatorname{ess} B, \operatorname{ess} C / \operatorname{es} x C, \operatorname{ess} D / e s x D)$ previously described as a versatile secretion system in $S$. aureus that might be involved in the transport 
of protein and or DNA [71]. The strains resulted positive for the staphylococcal enterotoxins genes commonly reported as a causative agent of food poisoning. With the use of the novel ABRicate database for enterotoxins and their variants, further enterotoxin genes were identified, which completed the comprehensive portraits of the strains presented in this study. The genomes were used to construct the pangenome of enterotoxigenic $S$. aureus, and the enterotoxin selX was detected as a component of the core genome [34]. The gene for this toxin is encoded in the core genome of $95 \%$ of phylogenetically diverse $S$. aureus strains, according to a study that included strains isolated in the case of human and animal infections [102]. Other enterotoxins were detected in mobile genetic elements, in particular, the prophage regions coding for the enterotoxin type E ( $\Phi \mathrm{N} 315$ and $\Phi$ Sa119) that were found in the strain ProNaCC2 and the gene for the staphylococcal enterotoxin type A, which was detected in the strain

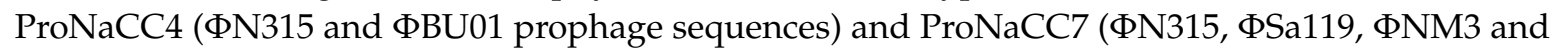
$\Phi B U 01$ prophage sequences), suggesting the phagic origin of these enterotoxins [23]. S. aureus acquires VFs encoded in the mobile genetic elements such as prophages but also plasmids, pathogenicity, and genomic islands, providing adaptation but also a genetic rearrangement resulting in hypervirulence of some strains but also the loss of portion of genes [44]. Interestingly, the sequences ent $A \_1-3$ were found in the genome of all the strains (Figure 6). These sequences are classified as enterotoxin family protein elements but they are not complete or have a low percentage of coverage and identity at the nucleotide level to the reference sequence of the enterotoxin type A. For this reason, the sequences of SEA genes were not confirmed with the database ABRicate for enterotoxins, confirming the importance of a validated database for staphylococcal enterotoxins that considers the manual validation of sequences.

The SaPIs database was used for evaluating the presence of enterotoxins in these genetic structures and at least one SaPI was found in each strain showing that SaPIs are widespread among the six enterotoxigenic strains. The sequences did not carry out SE genes but identical sequences among the strains were detected, also in the form of small fragments, explaining their phylogenetic relationship due probably to horizontal transfer.

The genes for the plasmid encoded enterotoxins SED, SEIJ and SER were found in the genome of the strains ProNaCC1 and ProNaCC7. The plasmid sequences found in the genome of the strain ProNaCC1 had a $98.11 \%$ coverage and $99.78 \%$ identity at the nucleotide level with the plasmid pLUH02 (accession number NZ_LJBK01000031.1) (Table S8), which was described in a strain responsible for two outbreaks in a maternity hospital in Belgorod, Russia [75]. The sequences of the S. aureus plasmid pSK67 (accession number GQ900447.1) were identified in the genome of the strain ProNaCC7 and had an $85.14 \%$ of coverage and $99.83 \%$ identity with the reference sequence (GQ900447.1) (Table S8). The gene coding enterotoxins (sed, selj, ser) were found within the sequences of the plasmids confirming their origin from mobile genetic elements.

The sequences of the plasmids detected in this study had similarity at nucleotide identity between 98.87\% and 99.96\% with the plasmids pIB485 (accession number AF053140.1 and M94872.1) and pF5 (accession number AB330135.1) reported in strains responsible for food poisoning [23,103,104]. However, the coverage corresponds only for the sequences of sed and selj, which are carried out in pIB485 and the gene selj and ser carried out in pF5, while both the strains (ProNaCC1 and ProNaCC7) carried out the sequences of the genes sed, selj, and ser in a unique putative plasmid region. In addition, the plasmid encoded genes involved in the arsenical resistance operon repressor (ars $R$ ) was detected in the two strains (Figure 8) along with the gene blaZ (Figure 9), responsible for the resistance to benzylpenicillin. The gene encoding the production of $\beta$-lactamases can be located in the chromosome, in plasmids, or in plasmid integrated into chromosome and transposon integrated into chromosome [105] and in these strains, the gene blaZ was detected within the plasmidic-origin enterotoxins, confirming the presence of the two plasmids, pLUH02 and pSK67, respectively, in the strain ProNaCC1 and ProNaCC7.

The strain ProNaCC5 resulted positive for several non-classical staphylococcal enterotoxin genes (seg, sei, sem, sen, and seo) and the staphylococcal enterotoxin-like genes (selu, selx, and sely). In Table 5, the position of start and end of the sequences within the contigs of the SEs genes was reported, and the 
genomic structure of the enterotoxin gene cluster which includes the genes for the enterotoxins SEG, SEI, SEM, SEN, SEO, and SEIU was demonstrated [106]. The strain was isolated in food suspected as responsible for SFP, but the method for the detection of enterotoxins did not identify any of the classical SEs. A strain with the same gene cluster, was responsible for an outbreak in Osaka city, Japan [107]. Unfortunately, also in this SFP, it was not possible to identify any classical enterotoxin in the food, similarly to the result obtained with the naturally-contaminated cheese, where the absence of enterotoxin SEA-SEE was confirmed (Table 6). Different studies revealed the isolation of staphylococcal strains implicated in SFP outbreaks in which classical SE genes were not detected, harbouring one or more of the new se/se-like genes, i.e., seg, seh, sei, or selj [37,108,109], and their toxins might have been the cause of these outbreaks. The genomic island vSa $\beta$ type III, contains the genes for serine proteases $(s p l C, s p l E$ and $s p l F)$ in addition to the SEs/SEl genes [23], but the strain ProNaCC5 resulted positive only for the gene $s p l E$, suggesting a possible variant of this genomic island.

The penicillinase encoded by blaZ was found in the strains ProNaCC1 and ProNaCC7, as previously reported. In this study, the gene was found in the plasmids pLUH02 and pSK67, detected in the strains ProNaCC1 and ProNaCC7, respectively. The strain ProNaCC1 resulted resistant to the antibiotic benzylpenicillin $(\geq 0.5 \mathrm{~g} / \mathrm{L})$, suggesting a role of the gene in the resistance mechanism. On the other hand, the strain ProNaCC7 resulted sensible at low concentrations of the antibiotic (0.06 g/L) (Table S11), and the strains ProNaCC6 resulted resistant $(\geq 0.5 \mathrm{~g} / \mathrm{L})$. The gene of the $S$. aureus fluoroquinolone efflux transporter protein NorA was detected in all the sequenced strains. The overexpression of this gene causes the resistance mechanism, but unfortunately transcriptional data were not included in this study. Nevertheless, all the strains resulted resistant to enrofloxacin at a concentration of $\leq 0.5 \mathrm{~g} / \mathrm{L}$.

The pangenome of the six enterotoxigenic $S$. aureus was assembled and applied to highlight the genetic, metabolic, and pathogenic diversity of the species in comparison with other 29 enterotoxigenic strains. Consistent with prior studies, the numbers of new genes per genome indicated substantial intraspecific variation and overall pangenome "openness" associated with a broad niche range $[110,111]$ but it is also a characteristic of populations that undergo frequent horizontal gene transfer [112]. In fact, $S$. aureus is a versatile microbe in complex microbial communities both in the environment or in a specific host, shifting between commensal or pathogenic variant $[113,114]$. Functional assignment of the core genes revealed that they are mostly associated with housekeeping functions (i.e., control of gene expression machinery and basic biochemistry). This confirms previous observations that S. aureus is a clonal species [115]. Recent studies have shown that even mutations in the core genome of closely related $S$. aureus isolates can have significant effects on virulence, proliferation, and persistence [116]. Thus, comparative studies are necessary to find these possible changes, and even more so, in enterotoxigenic strains that might be involved in food contaminants and foodborne outbreaks. A particular emphasis was placed on the analysis and distribution of enterotoxin genes among the six enterotoxigenic strains (Figure 11) and, the gene coding for the novel SAg staphylococcal enterotoxin-like toxin X (gene selx) was found in the core genome of the six enterotoxigenic strains; this result is comparable with another study where the gene was found in the core genome of $95 \%$ of a diverse $S$. aureus population, including isolates from human and animal infections [102]. The other genes coding for staphylococcal enterotoxins were detected onto mobile genetic elements (Table 7) and is one of the reasons why the pangenome resulted closed. In fact, the addition of other enterotoxigenic strains in the dataset does not provide new genes to the species pangenome. This feature is typical for species that live in isolated niches with limited access to the global microbial gene pool; indeed, the genomic and phenotypical diversity is due to the transfer of genetic material, including resistance genes and enterotoxins. Despite this, all the strains showed substantial differences regarding the accessory genes. Indeed, the six genomes we characterised by a highly dynamic mobilome (gene clusters, phage-related enterotoxins, SaPIs, and plasmids). In this study, 29 S. aureus genomes of isolates that were considered enterotoxin-producers in addition to reference strains used for the genome comparison were included. Interestingly, it was possible to identify other genes coding for enterotoxins in addition to the genes that were reported in the literature, especially novel enterotoxins that were not 
genetically characterized at the time of the publication of the sequences. This result underlines the importance of a novel bioinformatics approach for typing the enterotoxins which can be produced by S. aureus, and their use as a tool in support of diagnostics.

As demonstrated in different studies, food-related stress conditions, such as $\mathrm{NaCl}$, nitrite, glucose and lactic acid variations encountered during food production and preservation, can induce significant changes in the activity of SEB and SED promoter genes $[117,118]$. In this study six batches of cheese naturally contaminated with $S$. aureus strains were produced. The cheesemaking, followed a protocol that was published before by Bianchi et al. [119] for the production of naturally contaminated cheese with the enterotoxin type $\mathrm{D}$, and the parameters that would have altered the enterotoxigenic $S$. aureus cells or their survival during the ripening were not recorded. The enumeration of coagulase positive staphylococci (CPS) resulted high after the sweating process, between 2.5 and $5.6 \times 10^{8}$ CFU/g. In fact, according to the EC Regulation 2073/2005 on microbiological criteria for foodstuffs, when CPS enumeration exceeds $10^{5} \mathrm{CFU} / \mathrm{g}$ or $\mathrm{CFU} / \mathrm{mL}$, the samples must be tested for enterotoxins due to their presumed presence if the CPS population is constituted by enterotoxigenic strains. SEs detection methods rely on commercially available polyvalent enzyme-linked immunoassays (ELISA) or enzyme-linked fluorescent immunoassay (ELFA) with antibodies that detect SEA-SEE and the cheese samples spiked with the strain ProNaCC1-4 and ProNaCC7 resulted positive for at least one SE (Table 8). The strains ProNaCC5 and ProNaCC6 were isolated in cheese and in a composed salad, respectively (Table 1), and resulted both negative for the five detectable enterotoxins in the naturally-contaminated cheese study. Interestingly, the strain ProNaCC5 was isolated during a food poisoning investigation and were involved five patients with symptoms similar to staphylococcal food poisoning, and other pathogens in the foods were not isolated. From the genetic point of view the two strains are different; the strain ProNaCC6 resulted positive for the gene coding for the enterotoxin SEH, already reported as responsible for food-borne outbreaks and associated to a transposon [120,121] and the enterotoxin-like genes $\mathrm{X}$ (core genome) and $\mathrm{W}$, while the strain ProNaCC5 resulted positive for the genes carrying out the enterotoxin-like type $U, Y$, and $X$ (core genome) and the gene-cluster encoded enterotoxins (type $\mathrm{G}, \mathrm{I}, \mathrm{M}, \mathrm{N}, \mathrm{O}$ ). The egc enterotoxins or a combination of them (SEG, SEI, SEM, SEN, SEO) could have caused the SFP as reported in previous studies [31] supporting the involvement of the gene-cluster encoded enterotoxins rather than the core-genome enterotoxin-like in the event of foodborne poisoning caused by staphylococcal enterotoxins.

This study was limited to the genomic and in-silico prediction of the presence of VFs and SEs. Future developments and validation of methods for the detection of not-classical SEs and proteomic approaches will allow for a better understanding of in vivo production of the enterotoxins. The strains were whole-genome sequenced and were detected virulence factors, antimicrobial resistance genes, and mobile genetic elements with a specific focus on the staphylococcal enterotoxin and enterotoxin-like genes. Using novel databases offers a comprehensive portrait of enterotoxigenic strains of S. aureus used for the production of naturally-contaminated cheeses, and in the future, the identification of SEs and the development of innovative computational approaches will allow more accurate identification of additional genetic factors and genes necessary for the production of enterotoxins in food.

\section{Data Access}

The data have been deposited as a BioProject PRJNA419794 in the National Center for Biotechnology Information. The SRA are available at the following accession numbers: SRX3422350, SRX3422349, SRX3422348, SRX3422347, SRX3422346, SRX3422345.

Supplementary Materials: The following are available online at http://www.mdpi.com/2073-4425/11/1/33/s1, Database S1: Multifasta file containing the sequences of the virulence factors genes included in this study; Table S2: List of the strains used for building the pan-genome of enterotoxigenic S. aureus. Database S3: Multifasta file containing the 99 sequences of staphylococcal enterotoxins genes and their variants included in the ABRicate database; Table S4: Prophage most common regions within the six enterotoxigenic genomes detected in this study; Database S5: Multifasta file containing the 74 sequences of SaPIs included in the ABRicate database; Table S6: Details of the SaPIs detected in the samples with an identity percentage higher than 95.0; Database S7: Multifasta 
file containing the sequences of $S$. aureus plasmids included in the ABRicate database; Table S8: Details of the plasmids detected; Table S9: Sequences detected of bacteriocins and locus tags; Table S10: List of all the virulence factors detected and locus tags. Table S11: MIC values for all the antimicrobial tested in this study.

Author Contributions: G.M. conceived the study, drafted the manuscript, performed the data mining and the bioinformatics analysis; A.B. and S.G. designed the experiments for the cheese production and interpretation of the data; A.R. performed the library preparation and sequencing; D.M. and A.C. carried out reagents, field experiments and contributed to the design of the experiments; R.C.-R. perform the pangenome analysis; F.C., F.Z. and D.M.B. contributed to the interpretation and the modification of the data and the manuscript; L.D. and F.A. coordinate the project, proofread the manuscript and validate the data. All authors have read and agreed to the published version of the manuscript.

Funding: This research receives no external funding.

Acknowledgments: Research in the Decastelli's laboratory is funded by the Italian Ministry of Health in the form of a centre grant for the "National Reference Laboratory for Coagulase Positive Staphylococci, including S. aureus" The authors thanks Noémie Vingadassalon for the analysis of the EURL-CPS strains collection and selection; Isabelle Mutel and Florence Guillier for the toxin detection; Pascal Bouchez for the viability and curation of the collection and Jacques-Antoine Hennekinne for the scientific support.

Conflicts of Interest: The authors declare no conflict of interest.

\section{References}

1. MacLean, D.; Jones, J.D.; Studholme, D.J. Application of'next-generation'sequencing technologies to microbial genetics. Nat. Rev. Microbiol. 2009, 7, 287. [CrossRef] [PubMed]

2. Solieri, L.; Dakal, T.C.; Giudici, P. Next-generation sequencing and its potential impact on food microbial genomics. Ann. Microbiol. 2013, 63, 21-37. [CrossRef]

3. Bergholz, T.M.; Switt, A.I.M.; Wiedmann, M. Omics approaches in food safety: Fulfilling the promise? Trends Microbiol. 2014, 22, 275-281. [CrossRef] [PubMed]

4. Machida, M.; Asai, K.; Sano, M.; Tanaka, T.; Kumagai, T.; Terai, G.; Kusumoto, K.; Arima, T.; Akita, O.; Kashiwagi, Y.; et al. Genome sequencing and analysis of Aspergillus oryzae. Nature 2005, 438, 1157-1161. [CrossRef]

5. Ivanova, N.; Sorokin, A.; Anderson, I.; Galleron, N.; Candelon, B.; Kapatral, V.; Bhattacharyya, A.; Reznik, G.; Mikhailova, N.; Lapidus, A.; et al. Genome sequence of Bacillus cereus and comparative analysis with Bacillus anthracis. Nature 2003, 423, 87-91. [CrossRef]

6. Ward, T.J.; Ducey, T.F.; Usgaard, T.; Dunn, K.A.; Bielawski, J.P. Multilocus genotyping assays for single nucleotide polymorphism-based subtyping of Listeria monocytogenes isolates. Appl. Environ. Microbiol. 2008, 74, 7629-7642. [CrossRef]

7. Macori, G.; Cotter, P.D. Novel insights into the microbiology of fermented dairy foods. Curr. Opin. Biotechnol. 2017, 49, 172-178. [CrossRef]

8. Button, J.E.; Dutton, R.J. Cheese microbes. Curr. Biol. 2012, 22, R587-R589. [CrossRef]

9. Alemayehu, D.; Ross, R.P.; O'Sullivan, O.; Coffey, A.; Stanton, C.; Fitzgerald, G.F.; McAuliffe, O. Genome of a virulent bacteriophage Lb338-1 that lyses the probiotic Lactobacillus paracasei cheese strain. Gene 2009, 448, 29-39. [CrossRef]

10. Holden, M.T.; Hsu, L.Y.; Kurt, K.; Weinert, L.A.; Mather, A.E.; Harris, S.R.; Strommenger, B.; Layer, F.; Witte, W.; de Lencastre, H.; et al. A genomic portrait of the emergence, evolution, and global spread of a methicillin-resistant Staphylococcus aureus pandemic. Genome Res. 2013, 23, 653-664. [CrossRef]

11. Brunelle, B.W.; Bearson, B.L.; Bearson, S.M.D.; Casey, T.A. Multidrug-Resistant Salmonella enterica Serovar Typhimurium Isolates Are Resistant to Antibiotics That Influence Their Swimming and Swarming Motility. MSphere 2017, 2. [CrossRef] [PubMed]

12. Gnanasekaran, G.; Na, E.J.; Chung, H.Y.; Kim, S.; Kim, Y.T.; Kwak, W.; Kim, H.; Ryu, S.; Choi, S.H.; Lee, J.H. Genomic Insights and Its Comparative Analysis with Yersinia enterocolitica Reveals the Potential Virulence Determinants and Further Pathogenicity for Foodborne Outbreaks. J. Microbiol. Biotechnol. 2017, 27, 262-270. [CrossRef] [PubMed]

13. Köser, C.U.; Holden, M.T.; Ellington, M.J.; Cartwright, E.J.; Brown, N.M.; Ogilvy-Stuart, A.L.; Hsu, L.Y.; Chewapreecha, C.; Croucher, N.J.; Harris, S.R. Rapid whole-genome sequencing for investigation of a neonatal MRSA outbreak. N. Engl. J. Med. 2012, 366, 2267-2275. [CrossRef] [PubMed] 
14. Ghatak, S.; He, Y.; Reed, S.; Strobaugh, T., Jr.; Irwin, P. Whole genome sequencing and analysis of Campylobacter coli YH502 from retail chicken reveals a plasmid-borne type VI secretion system. Genom. Data 2017, 11, 128-131. [CrossRef]

15. Allard, M.W.; Bell, R.; Ferreira, C.M.; Gonzalez-Escalona, N.; Hoffmann, M.; Muruvanda, T.; Ottesen, A.; Ramachandran, P.; Reed, E.; Sharma, S.; et al. Genomics of foodborne pathogens for microbial food safety. Curr. Opin. Biotechnol. 2017, 49, 224-229. [CrossRef]

16. Li, Z.; Perez-Osorio, A.; Wang, Y.; Eckmann, K.; Glover, W.A.; Allard, M.W.; Brown, E.W.; Chen, Y. Whole genome sequencing analyses of Listeria monocytogenes that persisted in a milkshake machine for a year and caused illnesses in Washington State. BMC Microbiol. 2017, 17, 134. [CrossRef]

17. Nadon, C.; Van Walle, I.; Gerner-Smidt, P.; Campos, J.; Chinen, I.; Concepcion-Acevedo, J.; Gilpin, B.; Smith, A.M.; Man Kam, K.; Perez, E.; et al. PulseNet International: Vision for the implementation of whole genome sequencing (WGS) for global food-borne disease surveillance. Eurosurveillance 2017, 22. [CrossRef]

18. Deng, X.; Shariat, N.; Driebe, E.M.; Roe, C.C.; Tolar, B.; Trees, E.; Keim, P.; Zhang, W.; Dudley, E.G.; Fields, P.I.; et al. Comparative analysis of subtyping methods against a whole-genome-sequencing standard for Salmonella enterica serotype Enteritidis. J. Clin. Microbiol. 2015, 53, 212-218. [CrossRef]

19. Ransom, G.; Kaplan, B. USDA uses PulseNet for food safety. J. Am. Vet. Med. Assoc. 1998, 213, 1107.

20. Bergholz, T.M.; den Bakker, H.C.; Katz, L.S.; Silk, B.J.; Jackson, K.A.; Kucerova, Z.; Joseph, L.A.; Turnsek, M.; Gladney, L.M.; Halpin, J.L. Determination of evolutionary relationships of outbreak-associated Listeria monocytogenes strains of serotypes $1 / 2 \mathrm{a}$ and $1 / 2 \mathrm{~b}$ by whole-genome sequencing. Appl. Environ. Microbiol. 2016, 82, 928-938. [CrossRef]

21. Roetzer, A.; Diel, R.; Kohl, T.A.; Rückert, C.; Nübel, U.; Blom, J.; Wirth, T.; Jaenicke, S.; Schuback, S.; Rüsch-Gerdes, S. Whole genome sequencing versus traditional genotyping for investigation of a Mycobacterium tuberculosis outbreak: A longitudinal molecular epidemiological study. PLoS Med. 2013, 10, e1001387. [CrossRef] [PubMed]

22. Oakeson, K.F.; Wagner, J.M.; Rohrwasser, A.; Atkinson-Dunn, R. Whole-Genome Sequencing and Bioinformatic Analysis of Isolates from Foodborne Illness Outbreaks of Campylobacter jejuni and Salmonella enterica. J. Clin. Microbiol. 2018, 56. [CrossRef] [PubMed]

23. Authority, T.E.F.S. The European Union summary report on trends and sources of zoonoses, zoonotic agents and food-borne outbreaks in 2015. EFSA J. 2017, 15, 1-231. [CrossRef]

24. Argudin, M.A.; Mendoza, M.C.; Rodicio, M.R. Food poisoning and Staphylococcus aureus enterotoxins. Toxins 2010, 2, 1751-1773. [CrossRef] [PubMed]

25. Johler, S.; Weder, D.; Bridy, C.; Huguenin, M.C.; Robert, L.; Hummerjohann, J.; Stephan, R. Outbreak of staphylococcal food poisoning among children and staff at a Swiss boarding school due to soft cheese made from raw milk. J. Dairy Sci. 2015, 98, 2944-2948. [CrossRef]

26. Gallina, S.; Bianchi, D.M.; Bellio, A.; Nogarol, C.; Macori, G.; Zaccaria, T.; Biorci, F.; Carraro, E.; Decastelli, L. Staphylococcal poisoning foodborne outbreak: Epidemiological investigation and strain genotyping. J. Food Prot. 2013, 76, 2093-2098. [CrossRef]

27. Regulation (EC) No. 2073/2005 of the European Parliament and of the Council of 15 November 2005 on Microbiological Criteria for Foodstuffs. 2005. Available online: https://eur-lex.europa.eu/legal-content/EN/ TXT/PDF/?uri=CELEX:32005R2073\&from=EN (accessed on 27 September 2019).

28. Sato'o, Y.; Omoe, K.; Naito, I.; Ono, H.K.; Nakane, A.; Sugai, M.; Yamagishi, N.; Hu, D.L. Molecular epidemiology and identification of a Staphylococcus aureus clone causing food poisoning outbreaks in Japan. J. Clin. Microbiol. 2014, 52, 2637-2640. [CrossRef]

29. Fetsch, A.; Contzen, M.; Hartelt, K.; Kleiser, A.; Maassen, S.; Rau, J.; Kraushaar, B.; Layer, F.; Strommenger, B. Staphylococcus aureus food-poisoning outbreak associated with the consumption of ice-cream. Int. J. Food Microbiol. 2014, 187, 1-6. [CrossRef]

30. Macori, G.; Bellio, A.; Bianchi, D.M.; Gallina, S.; Adriano, D.; Zuccon, F.; Chiesa, F.; Acutis, P.L.; Casalinuovo, F.; Decastelli, L. Molecular Typing of Staphylococcus Aureus Isolate Responsible for Staphylococcal Poisoning Incident in Homemade Food. Ital. J. Food Saf. 2016, 5, 5736. [CrossRef]

31. Benkerroum, N. Staphylococcal enterotoxins and enterotoxin-like toxins with special reference to dairy products: An overview. Crit. Rev. Food Sci. Nutr. 2018, 58, 1943-1970. [CrossRef] 
32. Johler, S.; Giannini, P.; Jermini, M.; Hummerjohann, J.; Baumgartner, A.; Stephan, R. Further evidence for staphylococcal food poisoning outbreaks caused by egc-encoded enterotoxins. Toxins 2015, 7, 997-1004. [CrossRef] [PubMed]

33. Suzuki, Y.; Kobayashi, M.; Matsushita, S.; Uehara, S.; Kato, R.; Yusuke, S.O.; Ono, H.K.; Sadamasu, K.; Kai, A.; Kamata, Y. Detection of the staphylococcal enterotoxin D-like gene from staphylococcal food poisoning isolates over the last two decades in Tokyo. J. Vet. Med. Sci. 2015, 77, 905-911. [CrossRef] [PubMed]

34. Zhao, Y.; Zhu, A.; Tang, J.; Tang, C.; Chen, J.; Liu, J. Identification and measurement of staphylococcal enterotoxin-like protein I (SE 1l) secretion from Staphylococcus aureus clinical isolate. J. Appl. Microbiol. 2016, 121, 539-546. [CrossRef] [PubMed]

35. Grumann, D.; Nübel, U.; Bröker, B.M. Staphylococcus aureus toxins-their functions and genetics. Infect. Genet. Evol. 2014, 21, 583-592. [CrossRef] [PubMed]

36. Hu, D.L.; Ono, H.K.; Isayama, S.; Okada, R.; Okamura, M.; Lei, L.C.; Liu, Z.S.; Zhang, X.C.; Liu, M.Y.; Cui, J.C.; et al. Biological characteristics of staphylococcal enterotoxin $\mathrm{Q}$ and its potential risk for food poisoning. $J$. Appl. Microbiol. 2017, 122, 1672-1679. [CrossRef] [PubMed]

37. Ono, H.K.; Hirose, S.; Naito, I.; Sato'o, Y.; Asano, K.; Hu, D.L.; Omoe, K.; Nakane, A. The emetic activity of staphylococcal enterotoxins, SEK, SEL, SEM, SEN and SEO in a small emetic animal model, the house musk shrew. Microbiol. Immunol. 2017, 61, 12-16. [CrossRef]

38. Omoe, K.; Hu, D.-L.; Ono, H.K.; Shimizu, S.; Takahashi-Omoe, H.; Nakane, A.; Uchiyama, T.; Shinagawa, K.; Imanishi, K.I. Emetic potentials of newly identified staphylococcal enterotoxin-like toxins. Infect. Immun. 2013, 81, 3627-3631. [CrossRef]

39. Ono, H.K.; Sato'o, Y.; Narita, K.; Naito, I.; Hirose, S.; Hisatsune, J.; Asano, K.; Hu, D.L.; Omoe, K.; Sugai, M.; et al. Identification and Characterization of a Novel Staphylococcal Emetic Toxin. Appl. Environ. Microbiol. 2015, 81, 7034-7040. [CrossRef]

40. Dearborn, A.D.; Wall, E.A.; Kizziah, J.L.; Klenow, L.; Parker, L.K.; Manning, K.A.; Spilman, M.S.; Spear, J.M.; Christie, G.E.; Dokland, T. Competing scaffolding proteins determine capsid size during mobilization of Staphylococcus aureus pathogenicity islands. Elife 2017, 6, e30822. [CrossRef]

41. Wilson, G.J.; Tuffs, S.W.; Wee, B.A.; Seo, K.S.; Park, N.; Connelley, T.; Guinane, C.M.; Morrison, W.I.; Fitzgerald, J.R. Bovine Staphylococcus aureus superantigens stimulate the entire T cell repertoire of cattle. Infect. Immun. 2018, 86, e00505-e00518. [CrossRef]

42. Thomas, D.; Dauwalder, O.; Brun, V.; Badiou, C.; Ferry, T.; Etienne, J.; Vandenesch, F.; Lina, G. Staphylococcus aureus superantigens elicit redundant and extensive human Vbeta patterns. Infect. Immun. 2009, 77, 2043-2050. [CrossRef] [PubMed]

43. Zapotoczna, M.; Riboldi, G.P.; Moustafa, A.M.; Dickson, E.; Narechania, A.; Morrissey, J.A.; Planet, P.J.; Holden, M.T.; Waldron, K.J.; Geoghegan, J.A. Mobile-Genetic-Element-Encoded Hypertolerance to Copper Protects Staphylococcus aureus from Killing by Host Phagocytes. MBio 2018, 9, e00550-18. [CrossRef] [PubMed]

44. Partridge, S.R.; Kwong, S.M.; Firth, N.; Jensen, S.O. Mobile genetic elements associated with antimicrobial resistance. Clin. Microbiol. Rev. 2018, 31, e00088-17. [CrossRef] [PubMed]

45. Alibayov, B.; Zdenkova, K.; Sykorova, H.; Demnerova, K. Molecular analysis of Staphylococcus aureus pathogenicity islands (SaPI) and their superantigens combination of food samples. J. Microbiol. Methods 2014, 107, 197-204. [CrossRef] [PubMed]

46. Haaber, J.; Penadés, J.R.; Ingmer, H. Transfer of antibiotic resistance in Staphylococcus aureus. Trends Microbiol. 2017, 25, 893-905. [CrossRef] [PubMed]

47. Zeleny, R.; Nia, Y.; Schimmel, H.; Mutel, I.; Hennekinne, J.A.; Emteborg, H.; Charoud-Got, J.; Auvray, F. Certified reference materials for testing of the presence/absence of Staphylococcus aureus enterotoxin A (SEA) in cheese. Anal. Bioanal. Chem. 2016, 408, 5457-5465. [CrossRef]

48. Ostyn, A.; De Buyser, M.; Guillier, F.; Groult, J.; Felix, B.; Salah, S.; Delmas, G.; Hennekinne, J. First evidence of a food poisoning outbreak due to staphylococcal enterotoxin type E, France, 2009. Eurosurveillance 2010, $15,19528$.

49. Bellio, A.; Chiesa, F.; Gallina, S.; Bianchi, D.M.; Macori, G.; Bossi, D.; Nia, Y.; Mutel, I.; Messio, S.; Hennekinne, J.A.; et al. Insight into the Distribution of Staphylococci and Their Enterotoxins in Cheeses Under Natural Conditions. Front. Microbiol. 2018, 9, 3233. [CrossRef] 
50. De Buyser, M.-L.; Grout, J.; Brisabois, A.; Assere, A.; Lombard, B. Detection of genes encoding staphylococcal enterotoxins. Mult. PCR Sea See Ser Method CRL Coagulase Posit. Staphylococci Incl. Staphylococcus Aureus 2009, 1-5.

51. Enright, M.C.; Day, N.P.; Davies, C.E.; Peacock, S.J.; Spratt, B.G. Multilocus sequence typing for characterization of methicillin-resistant and methicillin-susceptible clones ofStaphylococcus aureus. J. Clin. Microbiol. 2000, 38, 1008-1015.

52. Harmsen, D.; Claus, H.; Witte, W.; Rothgänger, J.; Claus, H.; Turnwald, D.; Vogel, U. Typing of methicillin-resistant Staphylococcus aureus in a university hospital setting by using novel software for spa repeat determination and database management. J. Clin. Microbiol. 2003, 41, 5442-5448. [CrossRef] [PubMed]

53. Stegger, M.; Andersen, P.S.; Kearns, A.; Pichon, B.; Holmes, M.A.; Edwards, G.; Laurent, F.; Teale, C.; Skov, R.; Larsen, A.R. Rapid detection, differentiation and typing of methicillin-resistant Staphylococcus aureus harbouring either mecA or the new mecA homologue mecA(LGA251). Clin. Microbiol. Infect. 2012, 18, 395-400. [CrossRef] [PubMed]

54. Andrews, S. FastQC. Qual. Control Tool High Throughput Seq. Data 2010, 370. Available online: http://www.bioinformatics.babraham.ac.uk/projects/fastqc (accessed on 27 December 2019).

55. Bolger, A.M.; Lohse, M.; Usadel, B. Trimmomatic: A flexible trimmer for Illumina sequence data. Bioinformatics 2014, 30, 2114-2120. [CrossRef] [PubMed]

56. Bankevich, A.; Nurk, S.; Antipov, D.; Gurevich, A.A.; Dvorkin, M.; Kulikov, A.S.; Lesin, V.M.; Nikolenko, S.I.; Pham, S.; Prjibelski, A.D.; et al. SPAdes: A new genome assembly algorithm and its applications to single-cell sequencing. J. Comput. Biol. 2012, 19, 455-477. [CrossRef] [PubMed]

57. Gurevich, A.; Saveliev, V.; Vyahhi, N.; Tesler, G. QUAST: Quality assessment tool for genome assemblies. Bioinformatics 2013, 29, 1072-1075. [CrossRef] [PubMed]

58. Seemann, T. Prokka: Rapid prokaryotic genome annotation. Bioinformatics 2014, 30, 2068-2069. [CrossRef] [PubMed]

59. Overbeek, R.; Olson, R.; Pusch, G.D.; Olsen, G.J.; Davis, J.J.; Disz, T.; Edwards, R.A.; Gerdes, S.; Parrello, B.; Shukla, M.; et al. The SEED and the Rapid Annotation of microbial genomes using Subsystems Technology (RAST). Nucleic Acids Res. 2014, 42, D206-D214. [CrossRef]

60. Wattam, A.R.; Davis, J.J.; Assaf, R.; Boisvert, S.; Brettin, T.; Bun, C.; Conrad, N.; Dietrich, E.M.; Disz, T.; Gabbard, J.L. Improvements to PATRIC, the all-bacterial bioinformatics database and analysis resource center. Nucleic Acids Res. 2016, 45, D535-D542. [CrossRef]

61. Jolley, K.A.; Maiden, M.C. BIGSdb: Scalable analysis of bacterial genome variation at the population level. BMC Bioinform. 2010, 11, 595. [CrossRef]

62. van Heel, A.J.; de Jong, A.; Montalban-Lopez, M.; Kok, J.; Kuipers, O.P. BAGEL3: Automated identification of genes encoding bacteriocins and (non-) bactericidal posttranslationally modified peptides. Nucleic Acids Res. 2013, 41, W448-W453. [CrossRef]

63. Arndt, D.; Marcu, A.; Liang, Y.; Wishart, D.S. PHAST, PHASTER and PHASTEST: Tools for finding prophage in bacterial genomes. Brief. Bioinform. 2017, 20. [CrossRef] [PubMed]

64. Page, A.J.; Cummins, C.A.; Hunt, M.; Wong, V.K.; Reuter, S.; Holden, M.T.; Fookes, M.; Falush, D.; Keane, J.A.; Parkhill, J. Roary: Rapid large-scale prokaryote pan genome analysis. Bioinformatics 2015, 31, 3691-3693. [CrossRef] [PubMed]

65. Eren, A.M.; Esen, O.C.; Quince, C.; Vineis, J.H.; Morrison, H.G.; Sogin, M.L.; Delmont, T.O. Anvi'o: An advanced analysis and visualization platform for omics data. Peer] 2015, 3, e1319. [CrossRef] [PubMed]

66. Hadfield, J.; Croucher, N.J.; Goater, R.J.; Abudahab, K.; Aanensen, D.M.; Harris, S.R. Phandango: An interactive viewer for bacterial population genomics. Bioinformatics 2017, 34. [CrossRef] [PubMed]

67. Tatusov, R.L.; Galperin, M.Y.; Natale, D.A.; Koonin, E.V. The COG database: A tool for genome-scale analysis of protein functions and evolution. Nucleic Acids Res. 2000, 28, 33-36. [CrossRef]

68. Price, M.N.; Dehal, P.S.; Arkin, A.P. FastTree 2-approximately maximum-likelihood trees for large alignments. PLoS ONE 2010, 5, e9490. [CrossRef]

69. Ostyn, A.; Prufer, A.; Papinaud, I.; Hennekinne, J.; Assere, A.; Lombard, B. Detection of Staphylococcal Enterotoxins Types SEA to SEE in All Types of Food Matrices. In Proceedings of the European Screening Method of the EU-RL for Coagulase Positive Staphylococci including Staphylococcus, Aureus, France, September 2010; Version 5. pp. 1-12. 
70. International Organization for Standardization. ISO 6888-2 Microbiology of Food Animal Feeding Stuffs-Horizontal Method for the Enumeration of Coagulase-Positive Staphylococci (Staphylococcus Aureus and Other Species)_Part-2: Technique Using Rabbit Plasma Fibrynogen Agar Medium; International Organization for Standardization: Geneva, Switzerland, 1999; p. 7.

71. Ohr, R.J.; Anderson, M.; Shi, M.; Schneewind, O.; Missiakas, D. EssD, a Nuclease Effector of the Staphylococcus aureus ESS Pathway. J. Bacteriol. 2017, 199. [CrossRef]

72. Zoltner, M.; Ng, W.M.; Money, J.J.; Fyfe, P.K.; Kneuper, H.; Palmer, T.; Hunter, W.N. EssC: Domain structures inform on the elusive translocation channel in the Type VII secretion system. Biochem. J. 2016, 473, 1941-1952. [CrossRef]

73. Boutet, E.; Lieberherr, D.; Tognolli, M.; Schneider, M.; Bansal, P.; Bridge, A.J.; Poux, S.; Bougueleret, L.; Xenarios, I. UniProtKB/Swiss-Prot, the Manually Annotated Section of the UniProt KnowledgeBase: How to Use the Entry View. Methods Mol. Biol. 2016, 1374, 23-54. [CrossRef]

74. Rice, P.; Longden, I.; Bleasby, A. EMBOSS: The European Molecular Biology Open Software Suite. Trends Genet. 2000, 16, 276-277. [CrossRef]

75. Gill, S.R.; Fouts, D.E.; Archer, G.L.; Mongodin, E.F.; Deboy, R.T.; Ravel, J.; Paulsen, I.T.; Kolonay, J.F.; Brinkac, L.; Beanan, M.; et al. Insights on evolution of virulence and resistance from the complete genome analysis of an early methicillin-resistant Staphylococcus aureus strain and a biofilm-producing methicillin-resistant Staphylococcus epidermidis strain. J. Bacteriol. 2005, 187, 2426-2438. [CrossRef] [PubMed]

76. Abaev, I.; Skryabin, Y.; Kislichkina, A.; Bogun, A.; Korobova, O.; Mayskaya, N.; Shemyakin, I.; Dyatlov, I. Draft Genome Sequences of Exfoliative Toxin A-Producing Staphylococcus aureus Strains B-7772 and B-7777 (CC8/ST2993) and B-7774 (CC15/ST2126), Isolated in a Maternity Hospital in the Central Federal District of Russia. Genome Announc. 2016, 4. [CrossRef] [PubMed]

77. Truong-Bolduc, Q.C.; Zhang, X.; Hooper, D.C. Characterization of NorR protein, a multifunctional regulator of norA expression in Staphylococcus aureus. J. Bacteriol. 2003, 185, 3127-3138. [CrossRef] [PubMed]

78. Daly, K.M.; Upton, M.; Sandiford, S.K.; Draper, L.A.; Wescombe, P.A.; Jack, R.W.; O'Connor, P.M.; Rossney, A.; Götz, F.; Hill, C.; et al. Production of the Bsa lantibiotic by community-acquired Staphylococcus aureus strains. J. Bacteriol. 2010, 192, 1131-1142. [CrossRef]

79. Kérouanton, A.; Hennekinne, J.A.; Letertre, C.; Petit, L.; Chesneau, O.; Brisabois, A.; De Buyser, M.L. Characterization of Staphylococcus aureus strains associated with food poisoning outbreaks in France. Int. J. Food Microbiol. 2007, 115, 369-375. [CrossRef]

80. Guidi, F.; Duranti, A.; Gallina, S.; Nia, Y.; Petruzzelli, A.; Romano, A.; Travaglini, V.; Olivastri, A.; Calvaresi, V.; Decastelli, L.; et al. Characterization of A Staphylococcal Food Poisoning Outbreak in A Workplace Canteen during the Post-Earthquake Reconstruction of Central Italy. Toxins 2018, 10, 523. [CrossRef]

81. Li, G.; Wu, S.; Luo, W.; Su, Y.; Luan, Y.; Wang, X. Staphylococcus aureus ST6-t701 isolates from food-poisoning outbreaks (2006-2013) in Xi'an, China. Foodborne Pathog. Dis. 2015, 12, 203-206. [CrossRef]

82. Johler, S.; Tichaczek-Dischinger, P.S.; Rau, J.; Sihto, H.M.; Lehner, A.; Adam, M.; Stephan, R. Outbreak of Staphylococcal food poisoning due to SEA-producing Staphylococcus aureus. Foodborne Pathog. Dis. 2013, 10, 777-781. [CrossRef]

83. Mossong, J.; Decruyenaere, F.; Moris, G.; Ragimbeau, C.; Olinger, C.M.; Johler, S.; Perrin, M.; Hau, P.; Weicherding, P. Investigation of a staphylococcal food poisoning outbreak combining case-control, traditional typing and whole genome sequencing methods, Luxembourg, June 2014. Eurosurveillance 2015, 20. [CrossRef]

84. Crovadore, J.; Calmin, G.; Tonacini, J.; Chablais, R.; Baumgartner, A.; Schnyder, B.; Hodille, E.; Lefort, F. Whole-Genome Sequences of 15 Strains of Staphylococcus aureus subsp. aureus Isolated from Foodstuff and Human Clinical Samples. Genome Announc. 2015, 3. [CrossRef]

85. Naushad, S.; Naqvi, S.A.; Nobrega, D.; Luby, C.; Kastelic, J.P.; Barkema, H.W.; De Buck, J. Comprehensive Virulence Gene Profiling of Bovine Non-aureus Staphylococci Based on Whole-Genome Sequencing Data. MSystems 2019, 4. [CrossRef] [PubMed]

86. Bien, J.; Sokolova, O.; Bozko, P. Characterization of Virulence Factors of Staphylococcus aureus: Novel Function of Known Virulence Factors That Are Implicated in Activation of Airway Epithelial Proinflammatory Response. J. Pathog. 2011, 2011, 601905. [CrossRef] [PubMed]

87. Cramton, S.E.; Gerke, C.; Schnell, N.F.; Nichols, W.W.; Götz, F. The intercellular adhesion (ICA) locus is present in Staphylococcus aureus and is required for biofilm formation. Infect. Immun. 1999, 67, 5427-5433. [PubMed] 
88. Rode, T.M.; Langsrud, S.; Holck, A.; Møretrø, T. Different patterns of biofilm formation in Staphylococcus aureus under food-related stress conditions. Int. J. Food Microbiol. 2007, 116, 372-383. [CrossRef]

89. Møretrø, T.; Hermansen, L.; Holck, A.L.; Sidhu, M.S.; Rudi, K.; Langsrud, S. Biofilm formation and the presence of the intercellular adhesion locus ica among staphylococci from food and food processing environments. Appl. Environ. Microbiol. 2003, 69, 5648-5655. [CrossRef]

90. Corrigan, R.M.; Miajlovic, H.; Foster, T.J. Surface proteins that promote adherence of Staphylococcus aureus to human desquamated nasal epithelial cells. BMC Microbiol. 2009, 9, 22. [CrossRef]

91. Sharp, J.A.; Echague, C.G.; Hair, P.S.; Ward, M.D.; Nyalwidhe, J.O.; Geoghegan, J.A.; Foster, T.J.; Cunnion, K.M. Staphylococcus aureus surface protein $\mathrm{SdrE}$ binds complement regulator factor $\mathrm{H}$ as an immune evasion tactic. PLoS ONE 2012, 7, e38407. [CrossRef]

92. Åvall-Jääskeläinen, S.; Taponen, S.; Kant, R.; Paulin, L.; Blom, J.; Palva, A.; Koort, J. Comparative genome analysis of 24 bovine-associated. PeerJ 2018, 6, e4560. [CrossRef]

93. Rigoulay, C.; Entenza, J.M.; Halpern, D.; Widmer, E.; Moreillon, P.; Poquet, I.; Gruss, A. Comparative analysis of the roles of HtrA-like surface proteases in two virulent Staphylococcus aureus strains. Infect. Immun. 2005, 73, 563-572. [CrossRef]

94. Reed, S.B.; Wesson, C.A.; Liou, L.E.; Trumble, W.R.; Schlievert, P.M.; Bohach, G.A.; Bayles, K.W. Molecular characterization of a novel Staphylococcus aureus serine protease operon. Infect. Immun. 2001, 69, 1521-1527. [CrossRef]

95. Waryah, C.B.; Gogoi-Tiwari, J.; Wells, K.; Eto, K.Y.; Masoumi, E.; Costantino, P.; Kotiw, M.; Mukkur, T. Diversity of Virulence Factors Associated with West Australian Methicillin-Sensitive Staphylococcus aureus Isolates of Human Origin. BioMed Res. Int. 2016, 2016, 8651918. [CrossRef] [PubMed]

96. Ahmadrajabi, R.; Layegh-Khavidaki, S.; Kalantar-Neyestanaki, D.; Fasihi, Y. Molecular analysis of immune evasion cluster (IEC) genes and intercellular adhesion gene cluster (ICA) among methicillin-resistant and methicillin-sensitive isolates of Staphylococcus aureus. J. Prev. Med. Hyg. 2017, 58, E308-E314. [CrossRef] [PubMed]

97. Skaar, E.P.; Schneewind, O. Iron-regulated surface determinants (Isd) of Staphylococcus aureus: Stealing iron from heme. Microbes Infect. 2004, 6, 390-397. [CrossRef] [PubMed]

98. Abdelnour, A.; Arvidson, S.; Bremell, T.; Ryden, C.; Tarkowski, A. The accessory gene regulator (agr) controls Staphylococcus aureus virulence in a murine arthritis model. Infect. Immun. 1993, 61, 3879-3885. [PubMed]

99. Jenul, C.; Horswill, A.R. Regulation of Staphylococcus aureus Virulence. Microbiol. Spectr. 2018, 6. [CrossRef]

100. Fisher, E.L.; Otto, M.; Cheung, G.Y.C. Basis of Virulence in Enterotoxin-Mediated Staphylococcal Food Poisoning. Front. Microbiol. 2018, 9, 436. [CrossRef]

101. Dubrac, S.; Msadek, T. Identification of genes controlled by the essential YycG/YycF two-component system of Staphylococcus aureus. J. Bacteriol. 2004, 186, 1175-1181. [CrossRef]

102. Wilson, G.J.; Seo, K.S.; Cartwright, R.A.; Connelley, T.; Chuang-Smith, O.N.; Merriman, J.A.; Guinane, C.M.; Park, J.Y.; Bohach, G.A.; Schlievert, P.M.; et al. A novel core genome-encoded superantigen contributes to lethality of community-associated MRSA necrotizing pneumonia. PLoS Pathog. 2011, 7, e1002271. [CrossRef]

103. Ono, H.K.; Omoe, K.; Imanishi, K.; Iwakabe, Y.; Hu, D.L.; Kato, H.; Saito, N.; Nakane, A.; Uchiyama, T.; Shinagawa, K. Identification and characterization of two novel staphylococcal enterotoxins, types $\mathrm{S}$ and $\mathrm{T}$. Infect. Immun. 2008, 76, 4999-5005. [CrossRef]

104. Zhang, S.; Iandolo, J.J.; Stewart, G.C. The enterotoxin D plasmid of Staphylococcus aureus encodes a second enterotoxin determinant (sej). FEMS Microbiol. Lett. 1998, 168, 227-233. [CrossRef]

105. Lyon, B.R.; Skurray, R. Antimicrobial resistance of Staphylococcus aureus: Genetic basis. Microbiol. Rev. 1987, 51, 88-134. [PubMed]

106. Roetzer, A.; Gruener, C.S.; Haller, G.; Beyerly, J.; Model, N.; Eibl, M.M. Enterotoxin Gene Cluster-Encoded SEI and SEIN from Staphylococcus aureus Isolates are Crucial for the Induction of Human Blood Cell Proliferation and Pathogenicity in Rabbits. Toxins 2016, 8, 314. [CrossRef] [PubMed]

107. Umeda, K.; Nakamura, H.; Yamamoto, K.; Nishina, N.; Yasufuku, K.; Hirai, Y.; Hirayama, T.; Goto, K.; Hase, A.; Ogasawara, J. Molecular and epidemiological characterization of staphylococcal foodborne outbreak of Staphylococcus aureus harboring seg, sei, sem, sen, seo, and selu genes without production of classical enterotoxins. Int. J. Food Microbiol. 2017, 256, 30-35. [CrossRef] [PubMed] 
108. McLauchlin, J.; Narayanan, G.L.; Mithani, V.; O'Neill, G. The detection of enterotoxins and toxic shock syndrome toxin genes in Staphylococcus aureus by polymerase chain reaction. J. Food Prot. 2000, 63, 479-488. [CrossRef] [PubMed]

109. Omoe, K.; Ishikawa, M.; Shimoda, Y.; Hu, D.L.; Ueda, S.; Shinagawa, K. Detection of seg, seh, and sei genes in Staphylococcus aureus isolates and determination of the enterotoxin productivities of $\mathrm{S}$. aureus isolates Harboring seg, seh, or sei genes. J. Clin. Microbiol. 2002, 40, 857-862. [CrossRef]

110. Mira, A.; Martín-Cuadrado, A.B.; D’Auria, G.; Rodríguez-Valera, F. The bacterial pan-genome: A new paradigm in microbiology. Int. Microbiol. 2010, 13, 45-57. [CrossRef]

111. Jamrozy, D.M.; Harris, S.R.; Mohamed, N.; Peacock, S.J.; Tan, C.Y.; Parkhill, J.; Anderson, A.S.; Holden, M.T.G. Pan-genomic perspective on the evolution of the Staphylococcus aureus USA300 epidemic. Microb. Genom. 2016, 2, e000058. [CrossRef]

112. Méric, G.; Miragaia, M.; de Been, M.; Yahara, K.; Pascoe, B.; Mageiros, L.; Mikhail, J.; Harris, L.G.; Wilkinson, T.S.; Rolo, J.; et al. Ecological Overlap and Horizontal Gene Transfer in Staphylococcus aureus and Staphylococcus epidermidis. Genome Biol. Evol. 2015, 7, 1313-1328. [CrossRef]

113. Roach, D.J.; Burton, J.N.; Lee, C.; Stackhouse, B.; Butler-Wu, S.M.; Cookson, B.T.; Shendure, J.; Salipante, S.J. A Year of Infection in the Intensive Care Unit: Prospective Whole Genome Sequencing of Bacterial Clinical Isolates Reveals Cryptic Transmissions and Novel Microbiota. PLoS Genet. 2015, 11, e1005413. [CrossRef]

114. Bosi, E.; Monk, J.M.; Aziz, R.K.; Fondi, M.; Nizet, V.; Palsson, B. Comparative genome-scale modelling of Staphylococcus aureus strains identifies strain-specific metabolic capabilities linked to pathogenicity. Proc. Natl. Acad. Sci. USA 2016, 113, E3801-E3809. [CrossRef]

115. Feil, E.J.; Cooper, J.E.; Grundmann, H.; Robinson, D.A.; Enright, M.C.; Berendt, T.; Peacock, S.J.; Smith, J.M.; Murphy, M.; Spratt, B.G.; et al. How clonal is Staphylococcus aureus? J. Bacterial. 2003, 185, 3307-3316. [CrossRef] [PubMed]

116. Kennedy, A.D.; Otto, M.; Braughton, K.R.; Whitney, A.R.; Chen, L.; Mathema, B.; Mediavilla, J.R.; Byrne, K.A.; Parkins, L.D.; Tenover, F.C.; et al. Epidemic community-associated methicillin-resistant Staphylococcus aureus: Recent clonal expansion and diversification. Proc. Natl. Acad. Sci. USA 2008, 105, 1327-1332. [CrossRef] [PubMed]

117. Sihto, H.M.; Tasara, T.; Stephan, R.; Johler, S. Temporal expression of the staphylococcal enterotoxin D gene under $\mathrm{NaCl}$ stress conditions. FEMS Microbiol. Lett. 2015, 362. [CrossRef]

118. Sihto, H.M.; Stephan, R.; Engl, C.; Chen, J.; Johler, S. Effect of food-related stress conditions and loss of agr and sigB on seb promoter activity in S. aureus. Food Microbiol. 2017, 65, 205-212. [CrossRef] [PubMed]

119. Bianchi, D.M.; Ingravalle, F.; Adriano, D.; Gallina, S.; Gramaglia, M.; Zuccon, F.; Astegiano, S.; Bellio, A.; Macori, G.; Ru, G.; et al. Reproducibility study for the detection of Staphylococcal enterotoxins in dairy products between official Italian national laboratories. J. Food Prot. 2014, 77, 999-1004. [CrossRef]

120. Jørgensen, H.J.; Mathisen, T.; Løvseth, A.; Omoe, K.; Qvale, K.S.; Loncarevic, S. An outbreak of staphylococcal food poisoning caused by enterotoxin $\mathrm{H}$ in mashed potato made with raw milk. FEMS Microbiol. Lett. 2005, 252, 267-272. [CrossRef]

121. Pereira, M.L.; Carmo, L.S.D.; Santos, E.J.D.; Pereira, J.L.; Bergdoll, M.S. Enterotoxin H in Staphylococcal Food Poisoning. J. Food Prot. 1996, 59, 559-561. [CrossRef]

(C) 2019 by the authors. Licensee MDPI, Basel, Switzerland. This article is an open access article distributed under the terms and conditions of the Creative Commons Attribution (CC BY) license (http://creativecommons.org/licenses/by/4.0/). 